\title{
Transfer of organic carbon through marine water columns to sediments - insights from stable and radiocarbon isotopes of lipid biomarkers
}

\author{
S. G. Wakeham ${ }^{1}$ and A. P. McNichol $^{2}$ \\ ${ }^{1}$ Skidaway Institute of Oceanography, 10 Ocean Science Circle, Savannah, GA 31411, USA \\ ${ }^{2}$ National Ocean Sciences Accelerator Mass Spectrometer Facility (NOSAMS), \\ Woods Hole Oceanographic Institution, McLean Laboratory, Mail Stop \#8, 266 Woods Hole Road, \\ Woods Hole, MA 02543-1539, USA
}

Correspondence to: S. G. Wakeham (stuart.wakeham@skio.usg.edu)

Received: 16 May 2014 - Published in Biogeosciences Discuss.: 24 June 2014

Revised: 12 October 2014 - Accepted: 14 October 2014 - Published: 10 December 2014

\begin{abstract}
Compound-specific ${ }^{13} \mathrm{C}$ and ${ }^{14} \mathrm{C}$ compositions of diverse lipid biomarkers (fatty acids, alkenones, hydrocarbons, sterols and fatty alcohols) were measured in sinking particulate matter collected in sediment traps and from underlying surface sediments in the Black Sea, the Arabian Sea and the Ross Sea. The goal was to develop a multiparameter approach to constrain relative inputs of organic carbon (OC) from marine biomass, terrigenous vascular-plant and relict-kerogen sources. Using an isotope mass balance, we calculate that marine biomass in sediment trap material from the Black Sea and Arabian Sea accounted for $66-100 \%$ of OC, with lower terrigenous (3-8\%) and relict (4-16\%) contributions. Marine biomass in sediments constituted lower proportions of OC (66-90\%), with consequentially higher proportions of terrigenous and relict carbon (3-17 and 7$13 \%$, respectively). Ross Sea data were insufficient to allow similar mass balance calculations. These results suggest that, whereas particulate organic carbon is overwhelmingly marine in origin, pre-aged allochthonous terrigenous and relict OC become proportionally more important in sediments, consistent with pre-aged OC being better preserved during vertical transport to and burial at the seafloor than the upper-ocean-derived marine OC.
\end{abstract}

\section{Introduction}

The dynamics of sources, sinks and processes that control the burial of organic carbon (OC) in marine sediments have important implications for the global carbon cycle, paleoceanographic reconstructions and understanding climate variability (Berner, 1982; Hedges and Keil, 1995; Burdige, 2007; Zonneveld et al., 2010). Assigning the provenance of sedimentary OC remains a difficult task. Most burial occurs on continental margins where terrigenous material constitutes a significant proportion of the burial flux (Hedges et al., 1997; Burdige, 2005). But even at open-ocean locations remote from the continents where marine OC dominates the water column flux via the biological pump, a terrigenous component delivered by long-range aeolian transport (Zafiriou et al., 1995; Gagosian and Peltzer, 1986; Eglinton et al., 2002; Kawamura et al., 2003) is still recognizable in sediments (Prahl et al., 1989; Wakeham et al., 2002; Zonneveld et al., 2010). Myriad biogeochemical and sedimentological processes during transport through the marine water column and at the sediment-water interface affect the quantity and nature of sedimentary OC. The structural characterization of most marine organic matter is incomplete (Hedges et al., 2000; Lee et al., 2004), but it is generally thought that marine $\mathrm{OC}$ is more reactive than terrigenous plant and relict sediment OC (Cowie and Hedges, 1984; Wakeham et al., 1997). Even a small fraction of the most recalcitrant relict carbon is amenable to bacterial assimilation (Petsch et al., 2001, 2003; Pearson et al., 2005; Wakeham et al., 
2006). Selective enrichment of terrigenous OC in marine sediments over what is observed in the water column may result from differences in the intrinsic reactivity of the organic molecules themselves, protection by degradation-resistant macroorganic matrices and mineral surfaces, or environmental conditions (oxygen availability, oscillating redox, microbial consortia present) (Hedges and Keil, 1995; Hedges et al., 2001; Aller, 1994; Wakeham and Canuel, 2006; Burdige, 2007).

A suite of geochemical tools are applied to characterize the source(s) and fate of OC in the marine water column and sediments. Elemental compositions and ratios (e.g., OC/N) are often combined with carbon isotope analyses at the bulk level. Natural abundance stable carbon isotopes $\left(\delta^{13} \mathrm{C}\right)$ give insight into carbon source, carbon assimilation pathways and carbon flow in marine ecosystems and food webs (Hayes, 1993; Fry and Sherr, 1994; Freeman, 2001; Pearson, 2010). Natural-abundance radiocarbon analyses $\left(\Delta^{14} \mathrm{C}_{\mathrm{OC}}\right.$ or fraction modern $f_{\mathrm{m}}$ ) add the dimension of "age" to the character of organic matter and help define the residence time and redistribution of OC (Blair et al., 2003; Ingalls and Pearson, 2005; Griffith et al., 2010). Molecular analyses of biomarkers can distinguish between marine (e.g., sterols, alkenones), terrigenous (plant waxes and lignin phenols) and relict (alkanes with a carbon preference index of $\sim 1$ and often an unresolved complex mixture) materials in the heterogeneous mixture that is sedimentary OC. However, biomarker compounds are often present at low concentrations, and extrapolations to bulk OC are formidable. Single-compound (compound-specific) isotope analyses help in this respect because they combine the source specificity of biomarkers with $\delta^{13} \mathrm{C}_{\text {biomarker-derived information on carbon flow (Freeman }}$ et al., 1990; Hayes, 2001; Freeman, 2001) and $\Delta^{14} \mathrm{C}_{\text {biomarker- }}{ }^{-}$ derived ages that indicate the mixing of old with modern OC (Eglinton et al., 1997; McNichol and Aluwihare, 2007; Ingalls and Pearson, 2005). Early investigations in the marine water column showed that, whereas sinking particulate OC comprised of fresh planktonic detritus has a young radiocarbon age, surface sedimentary OC has older ages of a "pre-aged" and/or relict terrigenous component (Druffel et al., 1996; Wang et al., 1998; Hwang et al., 2010). Compound-specific radiocarbon measurements confirm preaged biomarkers in sedimentary OC (review by Ingalls and Pearson, 2005), and compound-class radiocarbon analyses have subsequently shown pre-aged OC in water column particulate matter (Wang et al., 2001; review by McNichol and Aluwihare, 2007). However, to date, combined biomarkerstable-carbon-radiocarbon studies of marine particulate matter are few (an exception being Ingalls et al., 2006), largely due to sample size limitations.

The present investigation attempts to fill this gap. The combination of lipid biomarker composition with molecular stable carbon and radiocarbon isotopes offers a threedimensional approach for investigating OC sources and transport and alteration processes in the ocean. In this study, compound-specific stable carbon and radiocarbon isotopes were measured on multiple lipid biomarkers in sinking particulate matter collected in sediment traps and from underlying surface sediments to evaluate the provenance of sedimentary organic matter. Three sets of paired sediment-trapsurface-sediment samples (POM - particulate organic matter; SOM - sedimentary organic matter) from the Black Sea, Arabian Sea and Ross Sea were investigated as representatives of oceanic regions characterized by widely disparate $\mathrm{OC}$ sources and depositional environments. Organic carbon content (\%OC), atomic $\mathrm{C} / \mathrm{N}$ ratios $\left(\mathrm{C} / \mathrm{N}_{(\mathrm{a})}\right), \delta^{13} \mathrm{C}$ and $\Delta^{14} \mathrm{C}$ of bulk materials and individual biomarkers (fatty acids, hydrocarbons, alkenones, alcohols and sterols) were measured to identify major molecular and isotopic compositions, and thereby shifts in relative amounts of marine, terrigenous (preaged vascular-plant-derived with continental residence times of decades to centuries) and relict (derived from eroded ancient sedimentary rocks and petrogenic material) carbon, in POM and underlying SOM. Throughout this discussion it is important to remember that the sediment trap samples are short snapshots in time (up to 6 months) whereas the surface sediments may represent centuries.

\section{Materials and methods}

\subsection{Study sites and samples}

Paired sediment trap and surface sediment $(\sim 0-2 \mathrm{~cm})$ samples from three settings (Fig. 1) were studied: the Black Sea (anoxic water column; high biogenic and high terrigenous OC); the Arabian Sea (oxygen minimum zone; high biogenic OC, low terrigenous OC); the Ross Sea, Antarctica (high biogenic flux, relict continental OC). The choice of these locations was predicated in part on the availability of large amounts of archived sinking particulate matter to facilitate compound-specific radiocarbon analyses.

\subsubsection{Black Sea}

The Black Sea site was in the southwestern Black Sea $\left(42^{\circ} \mathrm{N}\right.$, $32^{\circ} \mathrm{E}$ ), at station BS of the joint US-Turkish-German sediment trap program $50 \mathrm{~km}$ north of Asmara and $15 \mathrm{~km}$ from the base of the continental slope (Hay and Honjo, 1989; Hay et al., 1990). Anoxic conditions prevail below $\sim 120-150 \mathrm{~m}$ water depth (Sorokin, 1983). Underlying sediments contain up to $\sim 6 \%$ OC (Ross and Degens, 1974; Premuzic et al., 1982; Calvert et al., 1991). Biogenic and lithogenic particle fluxes and sediment accumulation have been reported by Hay (1987) and Hay et al. (1990). The site is offshore of the rugged Pontic Mountains on the north Anatolian coastline, and the continental margin is particularly steep, typically $6^{\circ}$ between 100 and $2000 \mathrm{~m}$ depths (Ross et al., 1974). Lithogenic material delivered by the Sarkarya Nehri, Filyos and Kocacay Rivers, usually during winter/spring, is deposited on the shelf, is frequently resuspended by storms 
and is subsequently transported offshore as either surface, mid-water $(\sim 150 \mathrm{~m}$ depth) or bottom-water nepheloid layers and turbidites; a surface plume extending out to the study site is sometimes visible on LANDSAT imagery (Hay, 1987). Sedimentation of lithogenic material out of the water column is enhanced by biogenic material derived from the annual succession of blooms of the coccolithophorid Emiliania huxleyi (spring) and pennate diatoms Rhizosolenia sp. (summer), producing the characteristic light-dark laminae (varve couplets) of Black Sea sediments (Hay, 1987; Hay et al., 1991). White laminae are comprised almost exclusively of coccolithophores of E. huxleyi, whereas dark laminae are predominately terrigenous clay minerals.

Sediment trap material (18.5 grams dry weight, gdw) from the moored BS trap at $\sim 250 \mathrm{~m}$ depth under strongly anoxic conditions is a composite of a 7-month-long time series collection (October 1985-April 1986). Trap material was preserved with buffered formalin and stored refrigerated at $4{ }^{\circ} \mathrm{C}$. Surface sediment $(0-2 \mathrm{~cm} ; 109.7 \mathrm{gdw})$ was composited from multicores collected at $2200 \mathrm{~m}$ water depth during the 1988 Black Sea expedition (Murray and Izdar, 1989; Hay and Honjo, 1989) at approximately the same location as the trap mooring. Sediments were stored frozen. Radiocarbon dating of sediments near the study site gave a sedimentation rate of $26 \mathrm{~cm} \mathrm{kyr}^{-1}$ (Arthur and Dean, 1998). Thus the $0-2 \mathrm{~cm}$ sediment interval represents approximately 1 century.

\subsubsection{Arabian Sea}

Arabian Sea samples were collected at mooring site MS-1 in the northwestern Arabian Sea (Oman Margin) during the US Joint Global Ocean Flux Study (JGOFS) Arabian Sea Process Study (ASPS) in 1994-1995 (Smith et al., 1998). MS-1 was approximately $160 \mathrm{~km}$ from the Oman coast off Ra's Sharbatat $\left(17^{\circ} 41^{\prime} \mathrm{N}, 58^{\circ} 51^{\prime \prime} \mathrm{E}\right)$ at a water depth of $1445 \mathrm{~m}$. High seasonal productivity during monsoon-driven upwelling enhances export into deep waters where remineralization of sinking organic matter depletes dissolved oxygen down to levels of $\sim 5 \mu \mathrm{M}$, producing the world's largest open-ocean oxygen minimum zone (OMZ) (Smith et al., 1998). More than $50 \%$ of the annual particle flux in the central Arabian Sea occurs during the boreal-summer southwest monsoon. Biogenic material, primarily diatom-derived, dominates over lithogenic material (Haake et al., 1996; Honjo et al., 1999), but some terrigenous material is delivered to the northwestern Arabian Sea as dust from the Horn of Africa (Somalia and Ethiopia) and from the Arabian Peninsula by strong summer monsoon winds (Ramage et al., 1972; Sirocko and Sarnthein, 1989; Dahl et al., 2005).

Sediment trap material ( $35.5 \mathrm{gdw}$ ) was a composite of material collected in time series traps deployed in the OMZ at $\sim 500$ and $\sim 900 \mathrm{~m}$ between May 1995 and January 1996, covering the southwest monsoon period (Wakeham et al., 2002). Mercuric chloride was used as a biocide. Upon recovery, trap samples were sealed and stored refrigerated at $4{ }^{\circ} \mathrm{C}$.

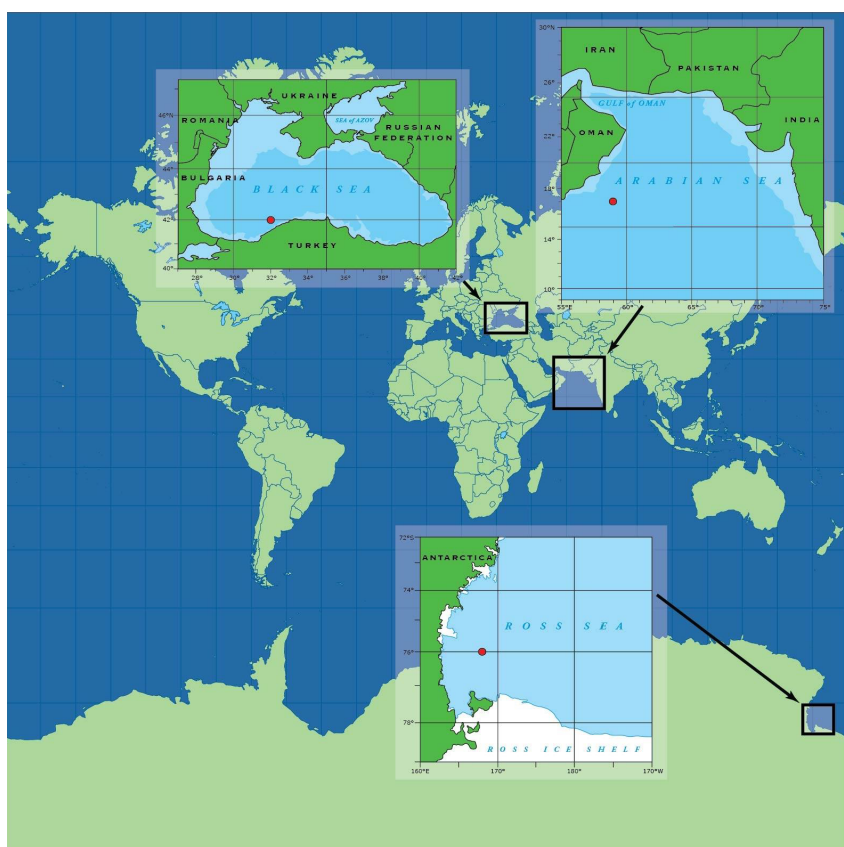

Figure 1. Sampling locations in the Black Sea, Arabian Sea and Ross Sea.

Surface sediments $(0-2 \mathrm{~cm})$ were composited $(142.7 \mathrm{gdw})$ from multicores collected in 1995 at the same location as the trap deployment and stored frozen. Passier et al. (1997) have estimated the sedimentation rate for this part of the Oman Margin at $5 \mathrm{~cm} \mathrm{kyr}^{-1}$; the sediment sample thus represents about 400 years.

\subsubsection{Ross Sea}

The Ross Sea site was in the southwestern Ross Sea where diatoms, primarily Nitzschia sp., and Phaeocystis antarctica dominate the phytoplankton community and vertical flux during the austral summer bloom (Arrigo et al., 2002; Dunbar et al., 2003). Sediments are largely biogenic oozes (biogenic silica $10-30 \%)$ with low OC $(0.1-3 \%$, averaging $1.5 \%$ ) and negligible biogenic carbonate (Dunbar et al., 1985, 1989). Terrigenous material, primary lithogenics with low OC content, is delivered by glaciers that drain the polar plateau and by aeolian transport from the ice-free Dry Valleys and accounts for 2-25\% of the vertical flux through the water column. In the western Ross Sea, ice-rafted debris constitutes $\sim 10 \%$ of sediments (Anderson et al., 1984) and aeolian sedimentation (either through sea ice or directly onto the sea surface) could be up to $50 \%$ of sediments in nearshore areas with limited glacial ice cover (Bentley, 1979, cited in Dunbar et al., 1989). Nonetheless, sedimentary OC is dominated by biogenic water column sources. Sediments are resuspended, mixed and redistributed within a pervasive nepheloid layer. 


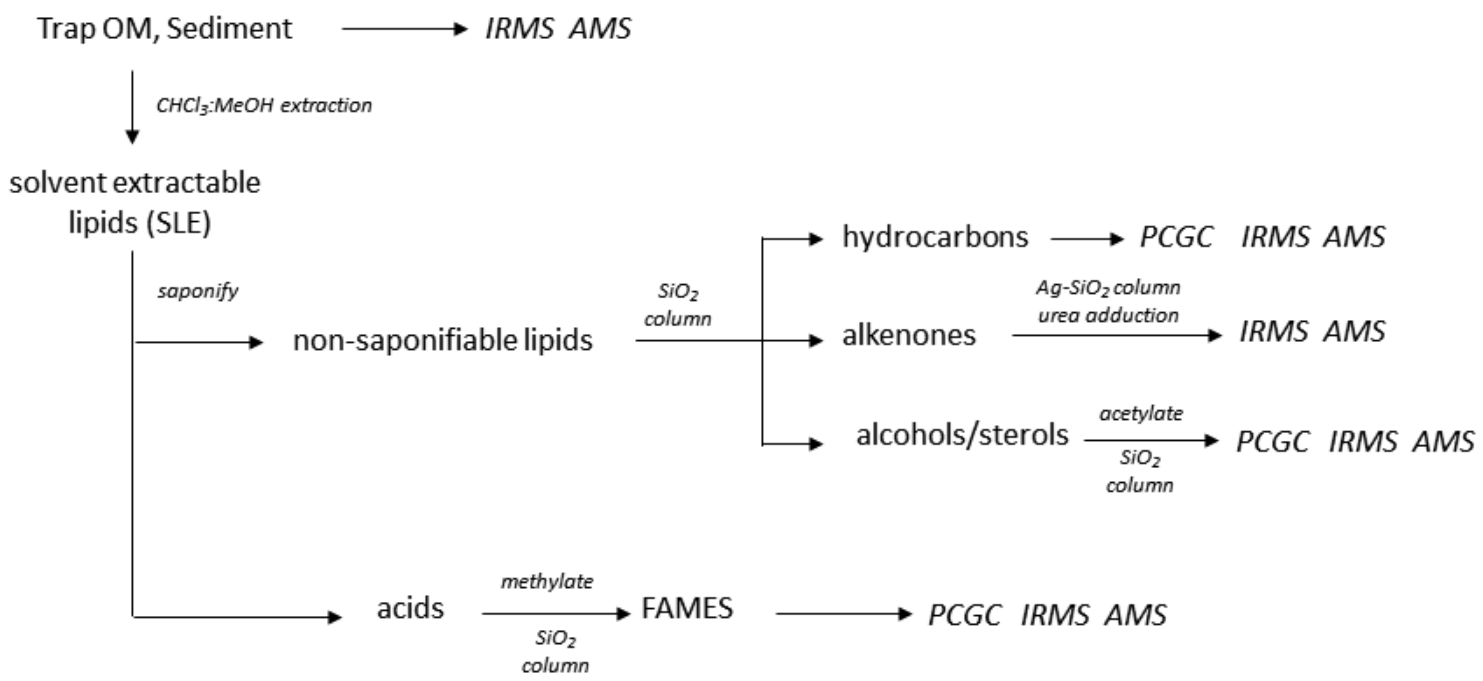

Figure 2. Scheme of extraction, isolation and analysis of biomarkers.

Ross Sea samples were collected during 1998 cruises of the ROAVERRS (Research on Ocean-Atmosphere Variability and Ecosystem Response in the Ross Sea) program (Dunbar et al., 2003). Trap material (48.2 gdw) came from Gentoo and Adelie time series traps located at about $76^{\circ} \mathrm{S}, 172^{\circ} \mathrm{E}$ in the southwestern Ross Sea and deployed $\sim 50 \mathrm{~m}$ above the sea floor in $650 \mathrm{~m}$ deep water (Dunbar et al., 2003). Trap material was preserved with $3 \%$ formalin and stored at $4{ }^{\circ} \mathrm{C}$. Surface sediments (515.1 gdw) were obtained from box cores (Ohkouchi et al., 2003) and stored frozen.

Sedimentation rate determinations for the Antarctic margin often use acid-insoluble organic carbon (AIOC) due to a lack of calcareous formaninifera (Domack et al. 1989; Licht et al., 1996; Harris et al. 1996; Andrew et al., 1999). DeMaster et al. (1996) reported AIOC-derived sedimentation rates in this region of the Ross Sea of $\sim 4.5 \mathrm{~cm} \mathrm{kyr}^{-1}$. AIOC-based chronology, however, is complicated by "contamination" by unknown amounts of relict OC (Sackett et al., 1974). To overcome this problem, Ohkouchi et al. (2003) applied a compound-specific radiocarbon analysis of sedimentary fatty acids for cores from the Gentoo and Adelie sites and found a 1200-2000 year offset between the ages of fatty acids and AIOC. The fatty acid-derived sedimentation rate was $7.5 \mathrm{~cm} \mathrm{kyr}^{-1}$ vs. an AIOC-derived rate of $15 \mathrm{~cm} \mathrm{kyr}^{-1}$. The sediment sample therefore represents $130-250$ years of deposition.

\subsection{Elemental analysis}

Freeze-dried and acidified (Hedges and Stern, 1984) trap material (bulk POM) and sediments (bulk SOM) were analyzed for organic carbon (\%OC) and total nitrogen (TN) with a Fisons (Model EA 1108) elemental analyzer.

\subsection{Lipid analysis}

The extraction, cleanup and isolation of fatty acids, hydrocarbons, alcohols and sterols by preparative capillary gas chromatography (PCGC; Eglinton et al., 1996) are outlined in Fig. 2. All laboratory glassware and $\mathrm{SiO}_{2}$ were precombusted at $500^{\circ} \mathrm{C}$ for $8 \mathrm{~h}$ before use. Freeze-dried POM and SOM were Soxhlet-extracted with methylene-chloride: methanol (DCM: $\mathrm{MeOH}, 2: 1 v / v$ ) for $72 \mathrm{~h}$. Extracts were washed with $5 \% \mathrm{NaCl}$ solution, and solvent lipid extracts (SLEs) were partitioned into DCM, after which the DCM fraction was dried over $\mathrm{Na}_{2} \mathrm{SO}_{4}$. SLEs were saponified using $0.5 \mathrm{~N}$ $\mathrm{KOH}$ at $100^{\circ} \mathrm{C}$ for $2 \mathrm{~h}$, and nonsaponifiable lipids were extracted out of the alkaline mixture with hexane after which the $\mathrm{pH}$ was adjusted to $<2$ with $6 \mathrm{~N} \mathrm{HCl}$, and acids were extracted with hexane. Nonsaponifiable lipids were fractionated on $5 \%$ deactivated silica gel into a hydrocarbon fraction eluted with hexane, an alkenone fraction eluted with $10 \%$ ethylacetate in hexane and an alcohol-sterol fraction eluted with $25 \%$ ethylacetate in hexane. Straight-chained hydrocarbons were separated from branched and cyclic hydrocarbons by urea adduction. Alkenones were isolated by sequential silica gel, $\mathrm{AgNO}_{3}$-silica gel chromatography and urea adduction after Ohkouchi et al. (2005). Alcohols and sterols were acetylated with pyridine and acetic anhydride. Acids were methylated with $\mathrm{BF}_{3}: \mathrm{MeOH}$, and the fatty acid methyl esters (FAMEs) were purified on columns of activated $\mathrm{SiO}_{2}$.

\subsection{Stable and radiocarbon analysis}

The isolation of purified individual hydrocarbons, sterol acetates, alcohol acetates and FAMEs was by preparative capillary gas chromatography (PCGC; Eglinton et al., 1996; Wakeham et al., 2006). An Agilent 5980II gas chromatograph equipped with an HP 7673 autoinjector, a 
Gerstel CIS-3 cooled injection system and a Gerstel preparative fraction collector (PFC) was fitted with an RTX-1 megabore $(60 \mathrm{~m} \times 0.53 \mathrm{~mm} \mathrm{ID} \times 0.5 \mu \mathrm{m}$ film $)$ capillary column. The GC temperature program was $60^{\circ} \mathrm{C}$ ( $\left.1 \mathrm{~min}\right)$, $20{ }^{\circ} \mathrm{C} \mathrm{min}^{-1}$ to $160{ }^{\circ} \mathrm{C}, 4^{\circ} \mathrm{C} \mathrm{min}^{-1}$ to $300^{\circ} \mathrm{C}$ and isothermal at $300^{\circ} \mathrm{C}$ for $20 \mathrm{~min}$. An effluent splitter directed $1 \%$ of the column effluent to the flame ionization detector, and the remaining $99 \%$ was sent to the zero-dead-volume splitter of the PFC. The PFC was operated at $320^{\circ} \mathrm{C}$, and U-tube traps were held at room temperature. Purified fractions were checked for purity and quantified by gas chromatographymass spectrometry (Agilent 6890 gas chromatograph, Agilent 5793 mass spectrometer, $30 \mathrm{~m} \times 0.25 \mathrm{~mm}$ ID J\&W DB-5 capillary column). Individual, composited compounds or operational classes were transferred to glass ampules and flamesealed for isotope analysis.

Stable and radiocarbon isotope measurements were made at the National Ocean Sciences Accelerator Mass Spectrometry (NOSAMS) Facility at the Woods Hole Oceanographic Institution. $\delta^{13} \mathrm{C}$ values are reported relative to the Vienna Pee Dee belemnite (precision $\pm 0.2 \%$ ), and $\Delta^{14} \mathrm{C}$ values are reported according to Stuiver and Polach (1977), using the year of sample collection for age correction. Acidified POM and SOM were transferred to precombusted Vycor tubes containing $\mathrm{CuO}$ and $\mathrm{Ag}$ powder. Sample extracts and isolated biomarkers were transferred with solvent to precombusted Vycor tubes, and after evaporating the solvent, $100 \mathrm{mg}$ precombusted $\mathrm{CuO}$ was added to the tube. Samples were combusted to $\mathrm{CO}_{2}$ at $850^{\circ} \mathrm{C}$ for 5 hours. After purification and quantification, a split of the $\mathrm{CO}_{2}$ was analyzed for $\delta^{13} \mathrm{C}$ on a VG Micromass Optima isotope ratio mass spectrometer. The remaining $\mathrm{CO}_{2}$ was reduced to filamentous graphite over either Fe or Co powder. Radiocarbon analyses of both large and small samples were performed using standard NOSAMS procedures (McNichol et al., 1994; von Reden et al., 1998; Pearson et al., 1998). Processing and combustion blanks of a hydrocarbon fraction isolated from a south Louisiana crude oil had replicate $\Delta^{14} \mathrm{C}$ values between -980 and $-998 \%$ ( $f_{\mathrm{m}} 0.03$ and 0.001 , respectively). Contributions of added methyl carbon derived from methanol in FAMEs and acetyl carbons from acetic anhydride in alcohol and sterol esters were removed by isotopic mass balance (Pearson, 2000; Wakeham et al., 2006). The $\delta^{13} \mathrm{C}$ and $\Delta^{14} \mathrm{C}$ values of carbon in the $\mathrm{BF}_{3}: \mathrm{MeOH}$ and acetic anhydride reagents were calculated by measuring the $\delta^{13} \mathrm{C}$ and $\Delta^{14} \mathrm{C}$ values of palmitic acid and cholesterol standards and of methyl palmitate and cholesteryl acetate prepared using the same lots of $\mathrm{BF}_{3}-\mathrm{MeOH}$ and acetic anhydride, respectively, and isolated by PCGC.

Several FAs (fatty acids) had unusually high $\Delta^{14} \mathrm{C}$ values and were not used in subsequent calculations of ranges, means and standard deviations of radiocarbon data (shown in bold italics in Tables 1-3). The reasons for these enrichments are unknown (see Wakeham et al. (2006) for additional discussion). Radiotracers had never been used in the Skid-
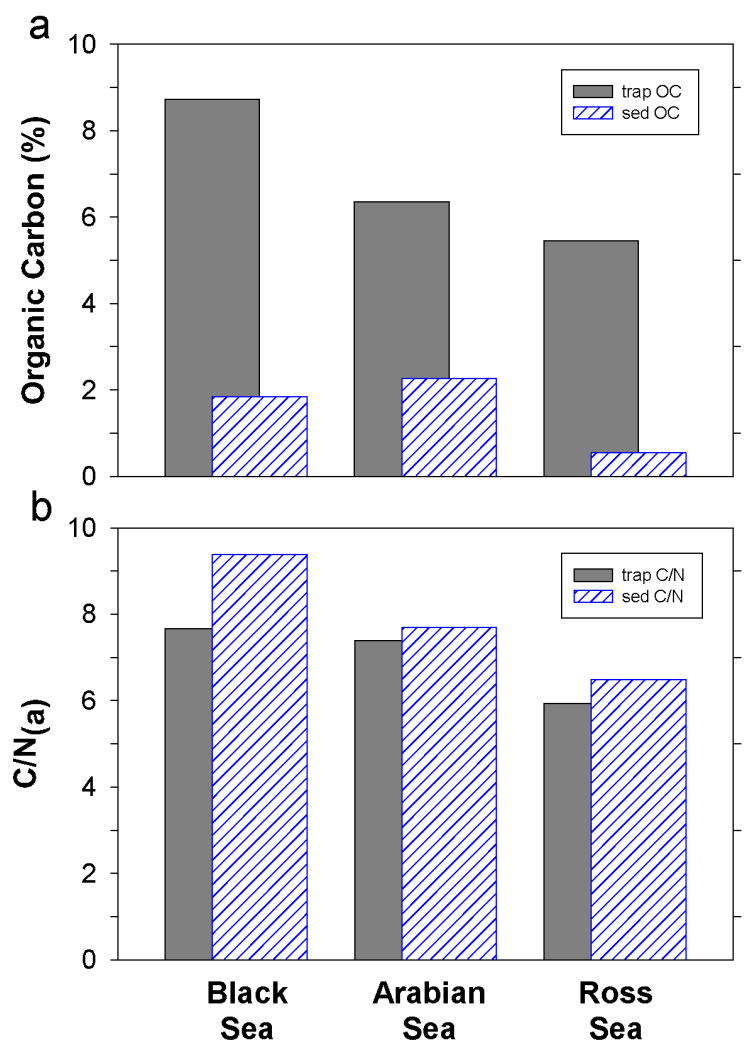

Figure 3. (a) Organic carbon $(\% \mathrm{OC})$ and (b) $\mathrm{C} / \mathrm{N}_{(\mathrm{a})}$ for bulk trap and sediments.

away Institute laboratory, which was thoroughly checked for any radiocarbon contamination, and crude-oil process blanks were free of modern carbon. The most enriched FA (most often but not always $16: 0,18: 1$ and $18: 0$ ) were compounds isolated in the highest concentrations and thus ones for which larger amounts of carbon were analyzed by accelerator mass spectrometry (AMS) rather than being the less abundant compounds. Such enrichments were not systematic, and in several cases replicate AMS analyses from splits of the same isolates were made, but with similar results indicating that any contamination must have occurred prior to or during PCGC workup. However, Levin and Kromer (1997) suggested that the average ${ }^{14} \mathrm{C}$ of atmospheric $\mathrm{CO}_{2}$ between 1980 and the present may have been $\sim 200 \%$ o, whereas analysis of post-bomb sediment from the Santa Monica Basin by Pearson and Eglinton (2000) indicates that an average ${ }^{14} \mathrm{C}$ of atmospheric $\mathrm{CO}_{2}$ around 1960 may have been $\sim 400 \%$ o. Thus while it is not possible to completely rule out the incorporation of higher amounts of post-bomb ${ }^{14} \mathrm{C}$ into these biomarker $\Delta^{14} \mathrm{C}$, other marine biomarkers and bulk $\mathrm{OC}$ are not consistent with such a scenario. 
Table 1. Stable carbon and radiocarbon isotope data for Black Sea POM and SOM. Bold italicized values were not used in calculations (see text).

\begin{tabular}{|c|c|c|c|c|c|c|}
\hline \multicolumn{7}{|c|}{ Black Sea trap } \\
\hline & Source & ID \# & $\delta^{13} \mathrm{C}(\% \circ)$ & $\Delta^{14} \mathrm{C}(\% \circ)$ & $f_{\mathrm{m}}$ & Age \\
\hline OC & & OS-32870 & -22.9 & $21 \pm 2$ & $1.026 \pm 0.003$ & $>$ Mod \\
\hline SLE & & OS-38316 & -27.2 & $-96 \pm 16$ & $0.909 \pm 0.016$ & $770 \pm 140$ \\
\hline $14: 0 \mathrm{FA}$ & M & OS-38328 & -25.6 & $132 \pm 13$ & $1.064 \pm 0.014$ & $>$ Mod \\
\hline $\mathrm{b}-15: 0 \mathrm{FA}$ & M & OS-38321 & -25.3 & $90 \pm 9$ & $1.029 \pm 0.011$ & $>$ Mod \\
\hline $16: 1 \mathrm{FA}$ & M & OS-38327 & -25.4 & $81 \pm 11$ & $1.025 \pm 0.011$ & $>$ Mod \\
\hline $16: 0 \mathrm{FA}$ & M & OS-38333 & -24.3 & $146 \pm 9$ & $1.086 \pm 0.011$ & $>$ Mod \\
\hline $18: 1 \mathrm{FA}$ & M & OS-38318 & -23.2 & $288 \pm 11$ & $1.228 \pm 0.008$ & $>$ Mod \\
\hline $18: 0 \mathrm{FA}$ & M & OS-38320 & -23.9 & $77 \pm 11$ & $1.028 \pm 0.011$ & $>$ Mod \\
\hline $24+26+28 \mathrm{FA}$ & $\mathrm{T}$ & OS-38331 & -27.0 & $1 \pm 16$ & $0.967 \pm 0.014$ & $265 \pm 110$ \\
\hline Alkenones & M & OS-39539 & -26.6 & $87 \pm 14$ & $1.099 \pm 0.014$ & $>\operatorname{Mod}$ \\
\hline $24+26+28 \mathrm{HC}$ & $\mathrm{R}$ & OS-39911 & -29.3 & $-677 \pm 10$ & $0.325 \pm 0.009$ & $9030 \pm 210$ \\
\hline $27+29 \mathrm{HC}$ & $\mathrm{T}$ & OS-39908 & -30.0 & $-181 \pm 14$ & $0.825 \pm 0.010$ & $1550 \pm 100$ \\
\hline $27 \Delta^{5}$ sterol & M & OS-53936 & -26.4 & $79 \pm 11$ & $1.046 \pm 0.011$ & > Mod. \\
\hline $28 \Delta^{5,22}$ sterol & M & OS-53934 & -26.1 & $65 \pm 9$ & $1.034 \pm 0.009$ & $>$ Mod. \\
\hline $30 \Delta^{22}$ sterol & M & OS-53957 & -25.7 & $69 \pm 15$ & $1.040 \pm 0.015$ & $>$ Mod \\
\hline $24+26+28 \mathrm{ROH}$ & $\mathrm{T}$ & OS-53956 & -30.1 & $-44 \pm 12$ & $0.925 \pm 0.012$ & $625 \pm 110$ \\
\hline \multicolumn{7}{|c|}{ Black Sea sediment } \\
\hline OC & & OS-32871 & -25.3 & $-199 \pm 6$ & $0.806 \pm 0.004$ & $1740 \pm 35$ \\
\hline SLE & & OS-38309 & -27.9 & $-150 \pm 15$ & $0.856 \pm 0.008$ & $1250 \pm 80$ \\
\hline $14: 0 \mathrm{FA}$ & M & OS-38630 & -28.6 & $18 \pm 15$ & $0.957 \pm 0.016$ & $350 \pm 130$ \\
\hline b-15:0 FA & M & OS-38632 & -30.5 & $-27 \pm 14$ & $0.919 \pm 0.019$ & $680 \pm 170$ \\
\hline $16: 1 \mathrm{FA}$ & M & OS-38628 & -31.9 & $75 \pm 14$ & $1.019 \pm 0.013$ & $>$ Mod \\
\hline $16: 0 \mathrm{FA}$ & M & OS-38627 & -29.1 & $214 \pm 18$ & $1.151 \pm 0.018$ & $>$ Mod \\
\hline b-17:0 FA & M & OS-38642 & -30.5 & $57 \pm 20$ & $1.006 \pm 0.020$ & $>$ Mod \\
\hline $18: 1 \mathrm{FA}$ & M & OS-38637 & -27.0 & $-24 \pm 20$ & $0.999 \pm 0.020$ & $5 \pm 100$ \\
\hline $18: 0 \mathrm{FA}$ & M & OS-38636 & -29.5 & $-374 \pm 27$ & $1.310 \pm 0.023$ & $>$ Mod \\
\hline $22: 0 \mathrm{FA}$ & M & OS-38639 & -28.9 & $-46 \pm 26$ & $0.919 \pm 0.027$ & $680 \pm 230$ \\
\hline $24: 0 \mathrm{FA}$ & M & OS-38640 & -29.2 & $-34 \pm 26$ & $0.934 \pm 0.024$ & $550 \pm 220$ \\
\hline $26: 0 \mathrm{FA}$ & $\mathrm{T}$ & OS-38641 & -30.5 & $-223 \pm 31$ & $0.754 \pm 0.021$ & $2270 \pm 230$ \\
\hline Alkenones & M & OS-39536 & -28.6 & $45 \pm 13$ & $1.069 \pm 0.013$ & $>$ Mod \\
\hline $24+26+28 \mathrm{HC}$ & $\mathrm{R}$ & OS-39909 & -29.2 & $-609 \pm 11$ & $0.393 \pm 0.007$ & $7500 \pm 150$ \\
\hline $27 \mathrm{HC}$ & $\mathrm{T}$ & OS-39907 & -30.0 & $-231 \pm 8$ & $0.774 \pm 0.011$ & $2060 \pm 110$ \\
\hline $29 \mathrm{HC}$ & $\mathrm{T}$ & OS-39906 & -31.0 & $-125 \pm 8$ & $0.880 \pm 0.008$ & $1020 \pm 75$ \\
\hline $27 \Delta^{5}$ sterol & M & OS-53948 & -27.0 & $-33 \pm 12$ & $0.937 \pm 0012$ & $520 \pm 100$ \\
\hline $30 \Delta^{22}$ sterol & M & OS-53943 & -26.0 & $-15 \pm 9$ & $0.942 \pm 0.011$ & $475 \pm 95$ \\
\hline $24 \mathrm{ROH}$ & $\mathrm{T}$ & OS-53951 & -29.7 & $-176 \pm 8$ & $0.796 \pm 0.011$ & $1840 \pm 110$ \\
\hline $26 \mathrm{ROH}$ & $\mathrm{T}$ & OS-53958 & -31.2 & $-100 \pm 16$ & $0.871 \pm 0.018$ & $1100 \pm 160$ \\
\hline
\end{tabular}

$\mathrm{M}$ stands for marine; $\mathrm{T}$ for terrigenous; $\mathrm{R}$ for relict

FA for fatty acid; $\mathrm{ROH}$ for alcohol; $\mathrm{HC}$ for alkane

\section{Results and discussion}

\subsection{Bulk elemental compositions}

Organic carbon contents (\%OC) of POM (Fig. 3a) were $8.7 \%$ in the Black Sea (BS), $6.4 \%$ in the Arabian Sea (AS) and $5.5 \%$ in the Ross Sea (RS). Total nitrogen (\%TN) contents were $1.1,0.86$ and $0.92 \%$, respectively, for the BS, AS and RS trap material. Thus, atomic $\mathrm{C} / \mathrm{N}$ ratios were 7.7, 7.4 and 5.9 (Fig. 3b). Sediment \%OC and \% $\%$ were lower: 1.8,
2.3 and $0.54 \%$ OC for the BS, AS and RS, respectively; 0.20 , 0.29 and $0.08 \% \mathrm{TN}$ for the BS, AS and RS, respectively. $\mathrm{C} / \mathrm{N}_{(\text {a) }}$ ratios for sediments were somewhat higher $(9.4,7.7$, 6.5 for BS, AS and RS, respectively) than for POM. Except for the BS sediment, $\mathrm{C} / \mathrm{N}_{(\mathrm{a})}$ ratios of the other trap and sediment samples were sufficiently Redfield-like to indicate the predominance of marine OC. The higher $\mathrm{C} / \mathrm{N}_{(\mathrm{a})}$ ratio of the BS sediment suggests a somewhat higher component of terrigenous OC; alternately, the higher $\mathrm{C} / \mathrm{N}_{(\mathrm{a})}$ ratio could result from preferential loss of nitrogen during degradation of OC, 
Table 2. Stable carbon and radiocarbon isotope data for Arabian Sea POM and SOM. Bold italicized values were not used in calculations (see text).

\begin{tabular}{|c|c|c|c|c|c|c|}
\hline \multicolumn{7}{|c|}{ Arabian Sea trap } \\
\hline & Source & ID \# & $\delta^{13} \mathrm{C}(\% \circ)$ & $\Delta^{14} \mathrm{C}(\% \circ)$ & $f_{\mathrm{m}}$ & Age \\
\hline $\mathrm{OC}$ & & OS-32868 & -22.4 & $14 \pm 13$ & $1.020 \pm 0.013$ & $>$ Mod \\
\hline SLE & & OS- 38314 & -24.7 & $66 \pm 14$ & $1.073 \pm 0.014$ & $>$ Mod \\
\hline $14: 0 \mathrm{FA}$ & M & OS- 37311 & -25.7 & $178 \pm 17$ & $1.107 \pm 0.017$ & $>$ Mod \\
\hline b-15: 0 FA & M & OS-37314 & -23.2 & $56 \pm 13$ & $0.997 \pm 0.014$ & $25 \pm 110$ \\
\hline $16: 1 \mathrm{FA}$ & M & OS-37304 & -24.0 & $55 \pm 21$ & $0.999 \pm 0.014$ & $5 \pm 100$ \\
\hline $16: 0 \mathrm{FA}$ & M & OS-37298 & -23.8 & $97 \pm 14$ & $1.039 \pm 0.013$ & $>\operatorname{Mod}$ \\
\hline $18: 1 \mathrm{FA}$ & M & OS-37297 & -23.1 & $38 \pm 21$ & $0.990 \pm 0.013$ & $80 \pm 100$ \\
\hline $18: 0 \mathrm{FA}$ & M & OS-37302 & -23.8 & $111 \pm 15$ & $1.060 \pm 0.015$ & $>$ Mod \\
\hline $22: 0 \mathrm{FA}$ & M & OS-37305 & -23.8 & $51 \pm 14$ & $1.012 \pm 0.014$ & $>$ Mod \\
\hline $24: 0 \mathrm{FA}$ & M & OS-37313 & -24.7 & $69 \pm 14$ & $1.033 \pm 0.013$ & $>$ Mod \\
\hline $26: 0 \mathrm{FA}$ & M & OS-37315 & -25.2 & $80 \pm 16$ & $1.047 \pm 0.016$ & $>$ Mod \\
\hline Alkenones & M & OS-39910 & -23.9 & $-6 \pm 9$ & $1.000 \pm 0.011$ & $>$ Mod \\
\hline $24+26+28 \mathrm{HC}$ & $\mathrm{R}$ & OS-55323 & -28.5 & $-731 \pm 14$ & $0.270 \pm 0.013$ & $10500 \pm 390$ \\
\hline HBI HC & M & OS-55248 & -24.5 & $-514 \pm 10$ & $0.488 \pm 0.010$ & $5750 \pm 160$ \\
\hline $27+29 \mathrm{HC}$ & $\mathrm{T}$ & OS-55325 & -28.4 & $-320 \pm 24$ & $0.684 \pm 0.024$ & $3050 \pm 280$ \\
\hline $27 \Delta^{5}$ sterol & M & OS-56344 & -16.7 & $-32 \pm 12$ & $0.939 \pm 0.012$ & $505 \pm 100$ \\
\hline $28 \Delta^{5,22}$ sterol & M & OS-56348 & -27.1 & $-86 \pm 13$ & $0.888 \pm 0.013$ & $955 \pm 120$ \\
\hline $16 \mathrm{ROH}$ & M & OS-56347 & -22.5 & $-91 \pm 12$ & $0.861 \pm 0.012$ & $1200 \pm 110$ \\
\hline \multicolumn{7}{|c|}{ Arabian Sea sediment } \\
\hline $\mathrm{OC}$ & & OS-32869 & -20.8 & $-138 \pm 2$ & $0.867 \pm 0.003$ & $1140 \pm 30$ \\
\hline SLE & & OS-38322 & -25.0 & $-173 \pm 11$ & $0.833 \pm 0.011$ & $1470 \pm 100$ \\
\hline $14: 0 \mathrm{FA}$ & M & OS-38332 & -26.6 & $-10 \pm 13$ & $0.931 \pm 0.013$ & $575 \pm 110$ \\
\hline b-15: 0 FA & M & OS-38324 & -24.5 & $-70 \pm 11$ & $0.878 \pm 0.011$ & $1040 \pm 100$ \\
\hline $16: 1 \mathrm{FA}$ & M & OS-38313 & -26.0 & $-112 \pm 7$ & $0.842 \pm 0.007$ & $1380 \pm 65$ \\
\hline $16: 0 \mathrm{FA}$ & M & OS- 38329 & -25.0 & $104 \pm 12$ & $1.046 \pm 0.012$ & $>$ Mod \\
\hline $18: 1 \mathrm{FA}$ & M & OS-38334 & -24.8 & $-171 \pm 13$ & $0.791 \pm 0.013$ & $1880 \pm 140$ \\
\hline $18: 0 \mathrm{FA}$ & M & OS-38325 & -24.7 & $190 \pm 10$ & $1.135 \pm 0.010$ & $>$ Mod \\
\hline $22: 0 \mathrm{FA}$ & M & OS-38326 & -26.8 & $103 \pm 12$ & $0.864 \pm 0.012$ & $1180 \pm 110$ \\
\hline $24: 0 \mathrm{FA}$ & M & OS-38317 & -25.4 & $-91 \pm 7$ & $0.879 \pm 0.006$ & $1040 \pm 55$ \\
\hline $26: 0 \mathrm{FA}$ & M & OS-38319 & -24.7 & $-116 \pm 7$ & $0.858 \pm 0.007$ & $1230 \pm 70$ \\
\hline Alkenones & M & OS-39902 & -24.1 & $-202 \pm 7$ & $0.803 \pm 0.003$ & $1760 \pm 65$ \\
\hline $24+26+28 \mathrm{HC}$ & $\mathrm{R}$ & OS-55329 & -27.6 & $-805 \pm 9$ & $0.197 \pm 0.008$ & $13050 \pm 340$ \\
\hline HBI HC & M & OS-56341 & -18.2 & $-256 \pm 8$ & $0.748 \pm 0.008$ & $2330 \pm 85$ \\
\hline $15+16+17+18 \mathrm{HC}$ & $\mathrm{R}$ & OS-55251 & -29.4 & $-887 \pm 5$ & $0.114 \pm 0.004$ & $17500 \pm 250$ \\
\hline $27+29 \mathrm{HC}$ & $\mathrm{T}$ & OS-55318 & -27.7 & $-430 \pm 11$ & $0.573 \pm 0.011$ & $4470 \pm 160$ \\
\hline $27 \Delta^{5}$ sterol & M & OS-56349 & -24.0 & $-152 \pm 13$ & $0.822 \pm 0.013$ & $1570 \pm 130$ \\
\hline $16 \mathrm{ROH}$ & M & OS-56351 & -23.3 & $-99 \pm 13$ & $0.853 \pm 0.012$ & $1270 \pm 110$ \\
\hline $26+28+30 \mathrm{ROH}$ & $\mathrm{T}$ & OS-56350 & -24.1 & $-113 \pm 14$ & $0.861 \pm 0.012$ & $1200 \pm 110$ \\
\hline
\end{tabular}

M stands for marine; $\mathrm{T}$ for terrigenous; $\mathrm{R}$ for relict

FA for fatty acid; ROH for alcohol; HC for alkane

but this process is likely limited by the anoxic water column of the BS.

\subsection{Bulk stable carbon isotopes}

BS and AS POM $\delta{ }^{13} \mathrm{C}_{\mathrm{OC}}$ values were typical for marinedominated OC: -22.9 and $-22.4 \%$ for the Black Sea and Arabian Sea, respectively (Fig. $4 a$ ). $\delta^{13} \mathrm{C}_{\mathrm{OC}}$ values for the corresponding SOM were both slightly more negative (BS: $-25.3 \%$ ) and more positive (AS: $-20.8 \%$ ) compared to the corresponding POM. The ${ }^{13} \mathrm{C}$-depletion in the $\mathrm{BS}$ sediment could reflect a greater long-term/time-averaged terrigenous $\mathrm{C}_{3}$-plant OC component (Collister et al., 1994; Conte and Weber, 2002; Chikaraishi et al., 2004) from the heavily wooded Anatolian coast than was present in the shortterm trap sample. The relative enrichment of the AS sediment compared to the trap material could be the result of the addition of isotopically enriched aeolian-transported OC derived from $\mathrm{C}_{4}$-grasses in the arid Horn of Africa and Arabian 
Table 3. Stable carbon and radiocarbon isotope data for Ross Sea POM and SOM. Bold italicized values were not used in calculations (see text).

\begin{tabular}{|c|c|c|c|c|c|c|}
\hline \multicolumn{7}{|c|}{ Ross Sea trap } \\
\hline & Source & ID \# & $\delta^{13} \mathrm{C}(\% o)$ & $\Delta^{14} \mathrm{C}(\% \circ)$ & $f_{\mathrm{m}}$ & Age \\
\hline $\mathrm{OC}$ & & OS-32872 & -28.0 & $-208 \pm 6$ & $0.797 \pm 0.004$ & $1820 \pm 40$ \\
\hline SLE & & OS-38330 & -32.7 & $-154 \pm 15$ & $0.852 \pm 0.015$ & $1290 \pm 140$ \\
\hline $14: 0 \mathrm{FA}$ & M & OS-38626 & -34.9 & $-115 \pm 14$ & $0.831 \pm 0.012$ & $1490 \pm 110$ \\
\hline $16: 0 \mathrm{FA}$ & M & OS-38624 & -31.7 & $-100 \pm 10$ & $0.853 \pm 0010$ & $1270 \pm 95$ \\
\hline $18: 0 \mathrm{FA}$ & M & OS-39272 & -35.3 & $-105 \pm 15$ & $0.854 \pm 0.015$ & $1270 \pm 140$ \\
\hline $22: 0+24: 0 \mathrm{FA}$ & M & OS-38635 & -31.8 & $-175 \pm 19$ & $0.796 \pm 0.019$ & $1830 \pm 190$ \\
\hline $27 \Delta^{5}$ sterol & M & OS-50105 & -32.0 & $-216 \pm 7$ & $0.761 \pm 0.007$ & $2190 \pm 75$ \\
\hline $28 \Delta^{5,22}$ sterol & M & OS-50107 & -35.4 & $-180 \pm 8$ & $0.796 \pm 0.007$ & $1830 \pm 70$ \\
\hline $14+16 \mathrm{ROH}$ & M & OS-50100 & -31.8 & $-191 \pm 9$ & $0.764 \pm 0.008$ & $2160 \pm 80$ \\
\hline \multicolumn{7}{|c|}{ Ross Sea sediment } \\
\hline $\mathrm{OC}$ & & OS-32873 & -27.9 & $-355 \pm 3$ & $0.649 \pm 0.003$ & $3480 \pm 35$ \\
\hline SLE & & OS-38323 & -30.0 & $-211 \pm 18$ & $0.795 \pm 0.018$ & $1850 \pm 180$ \\
\hline $14: 0 \mathrm{FA}$ & M & OS-38633 & -36.6 & $-83 \pm 5$ & $0.862 \pm 0.015$ & $1190 \pm 140$ \\
\hline br-15: 0 FA & M & OS-38625 & -32.3 & $-128 \pm 12$ & $0.824 \pm 0.012$ & $1560 \pm 120$ \\
\hline $16: 0 \mathrm{FA}$ & M & OS-39266 & -32.5 & $430 \pm 11$ & $1.439 \pm 0.011$ & $>$ Mod \\
\hline $18: 0 \mathrm{FA}$ & M & OS-38644 & -31.0 & $189 \pm 29$ & $1.196 \pm 0.029$ & $>$ Mod \\
\hline $24: 0 \mathrm{FA}$ & $\mathrm{T}$ & OS-38634 & -33.5 & $-208 \pm 22$ & $0.765 \pm 0.023$ & $2150 \pm 240$ \\
\hline $26: 0 \mathrm{FA}$ & $\mathrm{T}$ & OS-38645 & -30.3 & $-302 \pm 27$ & $0.677 \pm 0.029$ & $3130 \pm 340$ \\
\hline $27 \Delta^{5}$ sterol & M & OS-50108 & -33.0 & $-178 \pm 10$ & $0.798 \pm 0.010$ & $1810 \pm 95$ \\
\hline $28 \Delta^{5,22}$ sterol & M & OS-50106 & -34.3 & $-202 \pm 8$ & $0.775 \pm 0.007$ & $2050 \pm 70$ \\
\hline
\end{tabular}

FA stands for fatty acid; ROH stands for alcohol

Peninsula (Parker et al., 2004; Dahl et al., 2005), but again sampling timescales for trap and sediment are different.

The Ross Sea is a very different environment. Both POM and $\mathrm{SOM}$ had $\delta^{13} \mathrm{C}_{\mathrm{OC}}$ values of $-27.9 \%$, significantly isotopically depleted compared to BS and AS samples. Algal biomass at high latitudes is typically depleted in ${ }^{13} \mathrm{C}$ relative to algal OC at lower latitudes (Rau et al., 1991a, b; DeHairs et al., 1997; Freeman, 2001). Several factors may be involved in this differential photosynthetic isotope fractionation, including high algal growth rates, higher dissolved $\mathrm{CO}_{2}$ concentrations associated with low seawater temperatures and carbon assimilation mechanisms (Rau et al., 1991a, b; DeHairs et al., 1997; Freeman, 2001). In the open southwest Ross Sea, diatom and Phaeocystis biomass is -28 to $-27 \%$ (Villinski et al., 2000). Sea-ice algae would add ${ }^{13} \mathrm{C}$-enriched OC (Gleitz et al., 1996; Gibson et al., 1999; Villinski et al., 2000), but there is not a significant source of algal OC at the study site. Antarctic kerogen and coal have $\delta^{13} \mathrm{COC}_{\mathrm{OC}}$ values of -22 and $-24 \%$, respectively (Sackett, 1986; Burkins et al., 2000), and soils from the McMurdo Dry Valley region have a wide range of $\delta^{13} \mathrm{C}_{\mathrm{OC}}$ values: $\sim-30$ to $\sim-18 \%$ (and $\mathrm{C} / \mathrm{N}_{(\text {a) }}$ of $11 \pm 4$ ) (Burkins et al., 2000).

Solvent lipid extracts (SLE) would help bridge the gap between bulk OC and individual biomarkers. In all three sample pairs, SLEs were depleted by up to $4 \%$ in ${ }^{13} \mathrm{C}$ compared with the respective bulk OCs (Fig. $4 b$ ). $\delta^{13} \mathrm{C}_{\mathrm{SLE}}$ values for both traps and sediments followed the same trend among samples as $\delta^{13} \mathrm{C}_{\mathrm{OC}}: \delta^{13} \mathrm{C}_{\mathrm{AS}-\mathrm{SLE}}>\delta^{13} \mathrm{C}_{\mathrm{BS}-\mathrm{SLE}}$ $>\delta^{13} \mathrm{C}_{\mathrm{RS}-\mathrm{SLE}}$. Lipids are a relatively abundant fraction of OC in phytoplankton and zooplankton but are usually only a few percent of OC in particulate matter and sediments (Wakeham et al., 1997; Wang and Druffel, 2001). They would thus not be major contributors to particulate and sedimentary $\delta^{13} \mathrm{C}_{\mathrm{OC}}$ compared to more abundant proteins and carbohydrates that are $\sim 4-6 \%$ enriched in ${ }^{13} \mathrm{C}$ relative to lipids. Intraclass comparisons of isotopic compositions in marine systems are few. A study of $\delta^{13} \mathrm{C}$ of particulate and sedimentary OC in the northeast Pacific and Southern Oceans found that total hydrolyzable amino acids (THAA) and total carbohydrates (TCHO) in phytoplankton, zooplankton and sediments were enriched in ${ }^{13} \mathrm{C}$ by about $\sim 2$ and $\sim 3 \%$, respectively, relative to OC, whereas lipids were depleted by $\sim 4 \%$ o relative to OC (Wang et al., 1998; Wang and Druffel, 2001).

\subsection{Bulk radiocarbon isotopes}

Radiocarbon isotopic values were 21 and $14 \%$ for BS and AS trap OC $\left(\Delta^{14} \mathrm{C}_{\mathrm{OC}}\right)$ and -199 and $-138 \%$ or $\mathrm{BS}$ and AS sediments, respectively (Fig. $4 \mathrm{c}$ and Tables 1-3, which also list radiocarbon ages and fraction modern, $\left.f_{\mathrm{m}}\right)$. RS POM and SOM were depleted in ${ }^{14} \mathrm{C}(-208$ and $-355 \%$, respectively) relative to the two other sites. $\Delta{ }^{14} C_{\text {DIC }}$ values for prebomb and post-bomb mixed-layer DIC (dissolved inorganic 

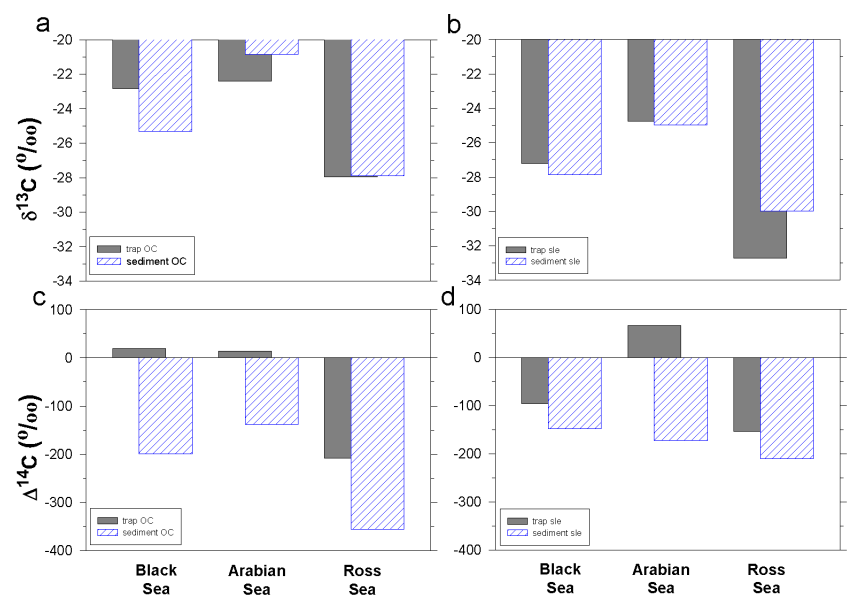

Figure 4. (a) The $\delta^{13} \mathrm{C}$ and (b) $\Delta^{14} \mathrm{C}$ values of bulk organic carbon (OC) and (c) $\delta^{13} \mathrm{C}$ and (d) $\Delta^{14} \mathrm{C}$ values solvent extractable lipids (SLE) for trap POM and sediments.

carbon) in the Black Sea are $\sim-70$ and $100 \%$, respectively (Jones and Gagnon, 1994) and in the AS they are $\sim-60$ and $\sim 70 \%$ o (Stuiver and Östlund, 1983; Southon et al., 2002); these values determine the $\Delta^{14} \mathrm{C}$ of autochthonous marine biomass. Pre-bomb and post-bomb $\Delta^{14} \mathrm{C}_{\mathrm{DIC}}$ values in the Ross Sea are lower than elsewhere: -130 and $-100 \%$, respectively (Berkman and Forman 1996; Gordon and Harkness 1992; Hall et al., 2010). In the AS and RS, upwelling of ${ }^{14} \mathrm{C}$-depleted deep waters and the short residence time of surface waters lead to the high surface-water reservoir ages $(\sim 700$ years and $\sim 1100$ years for AS and RS, respectively, vs. $\sim 400$ years for open-ocean locations, including the BS; Stuiver and Braziunas, 1993; Siani et al., 2000; Southon et al., 2002; Key, 2004; Hall et al., 2010). Thus trap OCs displayed post-bomb signatures for their respective regions but additionally contained older carbon, especially in the Ross Sea. Sediments contained significant contributions of old carbon, and corrected ${ }^{14} \mathrm{C}_{\mathrm{OC}}$ ages (Tables $1-3$ ) are significantly older than estimated geological ages (100-400 years, admittedly based on ${ }^{14} \mathrm{C}_{\mathrm{OC}}$-derived sedimentation rates).

Trap and sediment SLEs for the BS and RS had higher $\Delta^{14} \mathrm{C}_{\mathrm{SLE}}$ values than corresponding $\Delta^{14} \mathrm{C}_{\mathrm{OC}}$ values (Fig. 4d): $\Delta^{14} \mathrm{C}_{\text {SLE }}$ values were -96 and $-150 \%$ or BS trap and sediment, respectively, and -154 and $-211 \%$ for RS trap and sediment. That the BS and RS trap lipid fractions had lower $\Delta^{14} \mathrm{C}_{\mathrm{SLE}}$ values than $\Delta^{14} \mathrm{C}_{\mathrm{OC}}$ values indicates that some old carbon was extractable (e.g., plant waxes and petroleum hydrocarbons). But the higher sediment $\Delta^{14} \mathrm{C}_{\mathrm{SLE}}$ values than sediment $\Delta^{14} \mathrm{C}_{\mathrm{OC}}$ suggested that residual $\mathrm{OC}$ remaining after solvent extraction must be, by extension, something still older, such as nonextractable kerogen, especially in the RS sediment. On the other hand, $\Delta{ }^{14} \mathrm{C}_{\mathrm{SLE}}$ of the AS trap material was enriched (66\%) compared to the $\Delta^{14} \mathrm{C}_{\mathrm{OC}}$ value, but the sediment was depleted $(-173 \%$ ) relative to its $\Delta^{14} \mathrm{C}_{\mathrm{OC}}$ value. Thus solvent extraction of the AS trap mate-
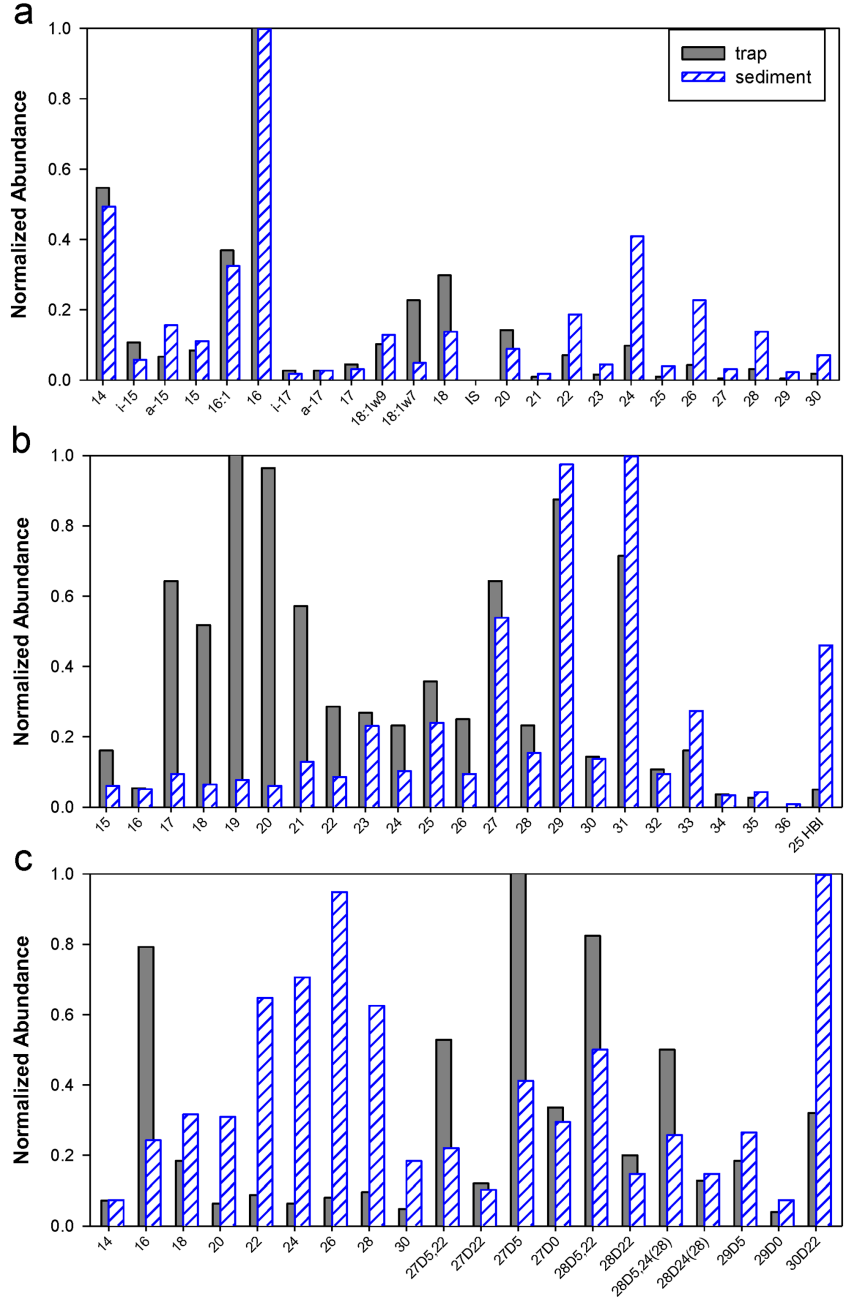

Figure 5. Histograms of relative abundances of (a) fatty acids, (b) hydrocarbons and (c) sterols/alcohols in POM and SOM from the Black Sea. Carbon numbers are given for fatty acids, alkanes and alcohols; sterol abbreviations are $27 \mathrm{D} 5,22=27 \Delta^{5,22}$, etc.

rial released a greater proportion of fresh, young algal lipid into the SLE, but extraction of the sediment recovered an SLE with a greater proportion of older lipid. In the only other reports, to our knowledge, that measured $\Delta^{14} \mathrm{C}_{\mathrm{SLE}}$ (Wang et al., 1998; Wang and Druffel, 2001), plankton and sedimentary lipids in the northeastern Pacific and Southern oceans were, respectively, similar to or lower than $\Delta^{14} \mathrm{C}$ of total OC. Lipids, THAA and TCHO all had similar $\Delta^{14} \mathrm{C}$ values in plankton, but in sediments lipids usually had lower $\Delta^{14} \mathrm{C}$ signatures than total hydrolyzable amino acids (THAA) and total carbohydrates (THCO).

\subsection{Biomarker molecular compositions}

Biomarker analyses focused on fatty acids, alkenones, fatty alcohols, sterols and hydrocarbons (Figs. 5-7). In the following discussion, the operational distinction is made 

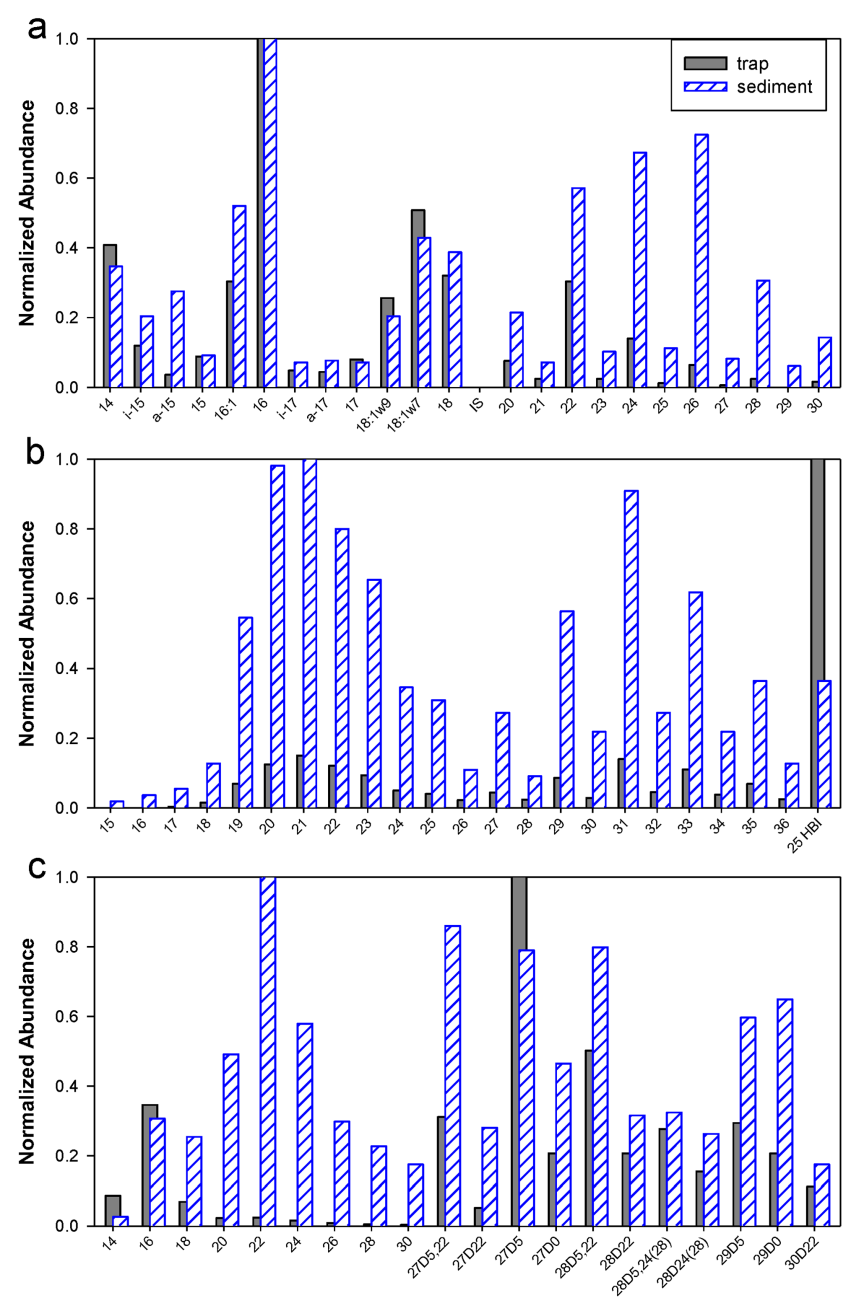

Figure 6. Histograms of relative abundances of (a) fatty acids, (b) hydrocarbons and (c) sterols/alcohols in POM and SOM from the Arabian Sea. Carbon numbers are given for fatty acids, alkanes and alcohols; sterol abbreviations are 27D5,22 $=27 \Delta^{5,22}$, etc.

between biomarkers of marine origin (hereafter termed "marine OC"), those derived from pre-aged terrestrial vascular plants ("terrigenous OC") and compounds originating from eroded ancient sediment or petrogenic sources ("relict OC"). In all POM samples, short-chain $\mathrm{C}_{14}-\mathrm{C}_{24} n$ - and methyl-branched iso- and anteiso- $\mathrm{C}_{15}$ and $\mathrm{C}_{17}$ compounds of marine biomass dominated fatty acid distributions (Volkman, 2006). Long-chain, even-carbon-number-predominant $\mathrm{C}_{24}-\mathrm{C}_{30}$ terrestrial vascular plant $n$-fatty acids were $\sim 10$ fold less abundant. Sediments contained similar fatty acid distributions but with higher relative abundances (but still $\sim$ 3-5-fold less abundant) of long-chain compounds. Longchain $\mathrm{C}_{37}-\mathrm{C}_{39}$ alkenones derived from the haptophyte, Emiliania huxleyi (Volkman et al., 1980), were abundant in BS (where coccoliths of E. huxleyi constitute the light laminae) and AS traps and sediments but absent from the RS. Low levels of hydrocarbons, a mix of $\mathrm{C}_{15}-\mathrm{C}_{36} n$-alkanes and an
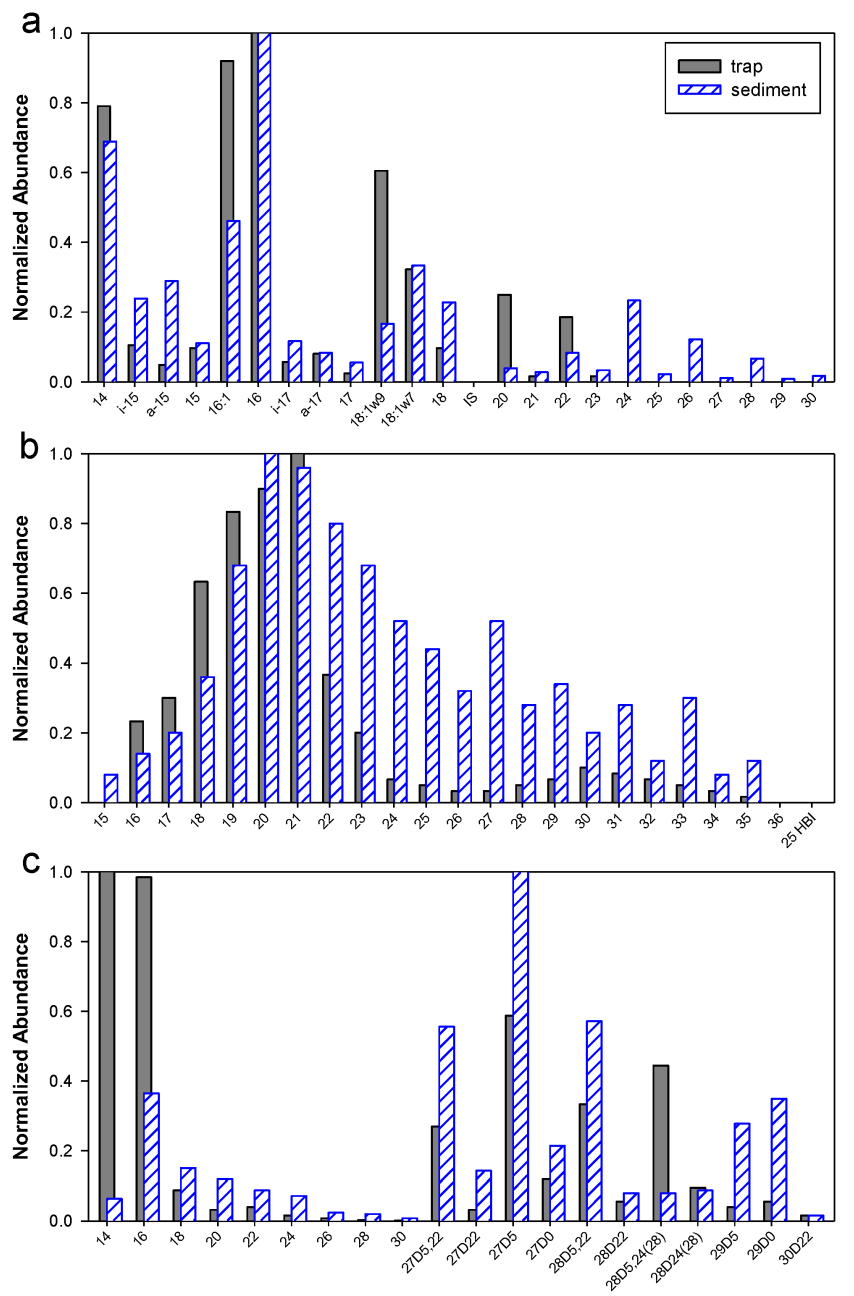

Figure 7. Histograms of relative abundances of (a) fatty acids, (b) hydrocarbons and (c) sterols/alcohols in POM and SOM from the Ross Sea. Carbon numbers are given for fatty acids, alkanes and alcohols; sterol abbreviations are 27D5,22 $=27 \Delta^{5,22}$, etc.

unresolved complex mixture (UCM) in the $\mathrm{C}_{14}-\mathrm{C}_{22}$ carbon number range were present in BS and AS samples at levels $\sim 10$-fold lower than fatty acids; none above blanks were detected in the RS. Short-chain $n$-alkanes $\left(\mathrm{C}_{16}-\mathrm{C}_{22}\right)$ showed no odd-over-even carbon number predominance (carbon preference index $\sim 1$ ) and were underlain by an unresolved complex mixture (UCM), whereas long-chain $n$-alkanes $\left(\mathrm{C}_{25}-\mathrm{C}_{31}\right)$ were odd-carbon predominant (CPI $\left.>5\right) . \mathrm{C}_{25}$ highly branched isoprenoid (HBI) alkenes of diatom origin were the dominant hydrocarbons in AS POM but were only minor components in BS POM and sediments and AS sediments. No hydrocarbons (above blanks) were detected in RS samples. All POM samples contained abundant $n$ hexadecanol (16 ROH, assumed to be derived primarily from zooplankton wax esters) and $\mathrm{C}_{27}-\mathrm{C}_{30}-\Delta^{5}, \Delta^{5,22}, \Delta^{5,24(28)}$ sterols [e.g., cholest-5-en-3 $\beta$-ol (cholesterol), abbreviated as $27 \Delta^{5}$; 24-methylcholesta-5,22-dien-3 $\beta$-ol, $28 \Delta^{5,22}$; 


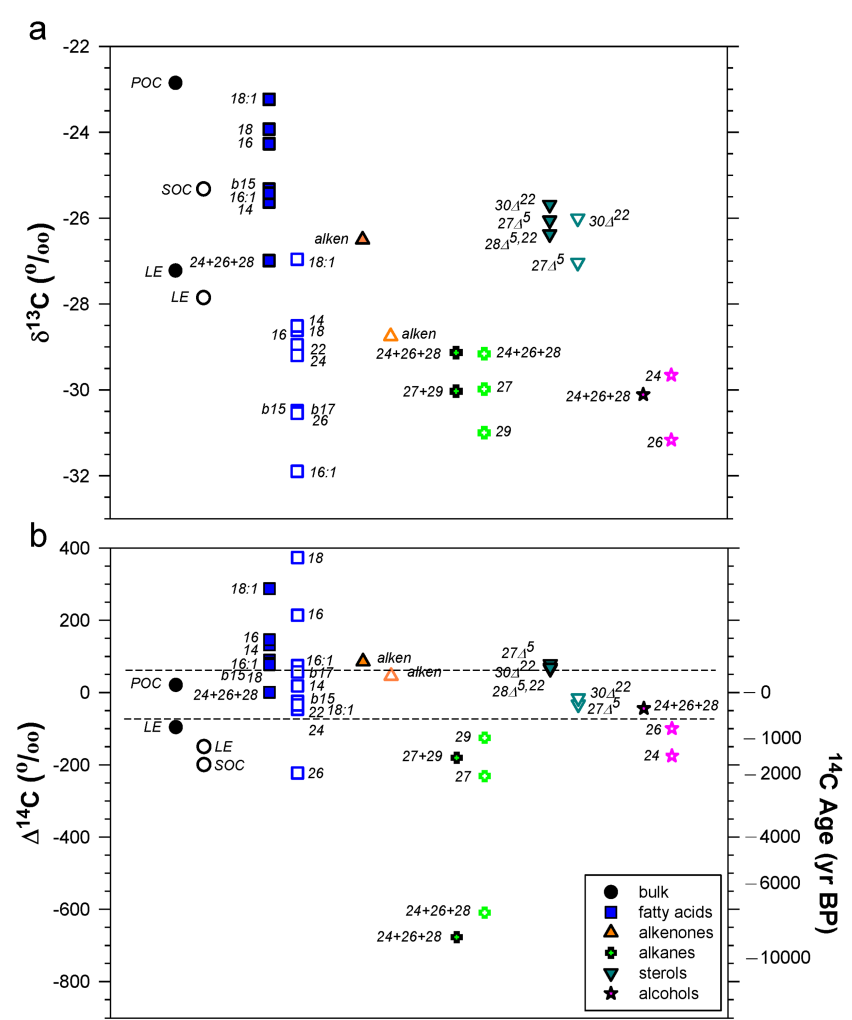

Figure 8. The (a) $\delta^{13} \mathrm{C}$ and (b ) $\Delta^{14} \mathrm{C}$ values of bulk POC and SOC and individual biomarkers for trap and sediments from the Black Sea (see also Table 1). Filled symbols are trap biomarkers; open symbols are sediment biomarkers. All values have been corrected for procedural blanks and any derivative carbon, as needed. Dashed lines are pre-bomb (lower) and post-bomb (upper) mixedlayer $\Delta^{14} C_{\text {DIC }}$.

24-methylcholesta-5,24(28)-dien-3 $\beta$-ol, $28 \Delta^{5,24(28)}$ and, in the BS, a significant amount of 4,23,24-trimethylcholest-22en-3 $\beta$-ol (dinosterol), $30 \Delta^{22}$ ], all of marine origin (Volkman, 2006). POM contained only low amounts of even-carbonnumber-predominant $\mathrm{C}_{24}-\mathrm{C}_{30} n$-alcohols produced by vascular plants, but sediments contained higher abundances of terrestrial $n$-alcohols than sterols.

\subsection{Biomarker isotopic compositions}

PCGC isolation for compound-specific isotope analyses targeted the most abundant biomarkers of marine, terrigenous plant and relict origins. Short-chain $n$-fatty acids $\left(\mathrm{C}_{14}-\mathrm{C}_{24}\right.$, abbreviated as 14:0 FA, etc.), $\mathrm{C}_{37}+\mathrm{C}_{38}$-alkenones, a shortchain $n$-fatty alcohol [16ROH ( $n$-hexadecanol)] and sterols [cholest-5-en-3 $\beta$-ol (cholesterol), abbreviated as $27 \Delta^{5}$; 24-methylcholesta-5,22-dien-3 $\beta$-ol, $28 \Delta^{5,22}$; and 4,23,24trimethylcholest-22-en-3 $\beta$-ol (dinosterol), $30 \Delta^{22}$ ] were designated as marine biomarkers. Long-chain even-carbonnumber $n$-acids $\left(\mathrm{C}_{26}-\mathrm{C}_{30}\right)$ and $n$-alcohols $\left(\mathrm{C}_{24}-\mathrm{C}_{28}\right)$ and long-chain odd-carbon-numbered $n$-alkanes $\left(\mathrm{C}_{27}\right.$ and $\left.\mathrm{C}_{29}\right)$ were tagged as terrigenous, vascular-plant markers; in some cases the long-chain fatty acids could be isolated individually but in other cases composites (e.g., $\mathrm{C}_{24}+\mathrm{C}_{26}+\mathrm{C}_{28}$ fatty acids) were required. Long-chain even-carbon-numbered $n$-alkanes (composited $\mathrm{C}_{24}+\mathrm{C}_{26}+\mathrm{C}_{28}$ ) and, in the AS sediment, short-chain $\mathrm{C}_{15}+\mathrm{C}_{16}+\mathrm{C}_{17}+\mathrm{C}_{18}$ alkanes (including some unresolved complex mixture that could not be removed) were used as relict markers since these alkanes are not abundant in marine or terrestrial biomass. As will be shown below, using long-chain $n$-alkanes as either terrigenous plant or relict markers is problematic because, in the present samples, there is overlap between odd- vs. even-chain lengths and plant vs. relict sources. Thus it is possible that long-chain $n$-alcohols, if present in sufficient abundances, may represent the best "terrigenous" biomarkers since they would have neither modern marine (major alcohols in wax esters are $\mathrm{C}_{16}$ and $\mathrm{C}_{18}$; Wakeham, 1982) nor relict sources. Highly branched $\mathrm{C}_{25}$ alkenes (HBI) of diatom origin (Belt et al., 2000) were the most abundant hydrocarbons in AS trap material, less so in AS sediments, but they were underlain by a UCM that could not be removed, thus yielding unrealistically ${ }^{14} \mathrm{C}$-depleted results. In the RS POM and SOM, only fatty acids, $16 \mathrm{ROH}$ and sterols (cholest-5-en- $3 \beta$-ol and 24 -methylcholesta-5,22-dien-3 $\beta$-ol) could be isolated. Stable carbon and radiocarbon isotope results were weighted according to their abundance within each sample to give means for each of the three sources (marine, terrigenous and relict) that are designated below as $\delta^{13} \mathrm{C}_{\mathrm{M}}$ and $\Delta^{14} \mathrm{C}_{\mathrm{M}}, \delta^{13} \mathrm{C}_{\mathrm{T}}$ and $\Delta{ }^{14} \mathrm{C}_{\mathrm{T}}$, and $\delta^{13} \mathrm{C}_{\mathrm{R}}$ and $\Delta{ }^{14} \mathrm{C}_{\mathrm{R}}$

\subsubsection{Black Sea}

For the Black Sea POM, short-chain fatty acids, long-chain alkenones and sterols had $\delta^{13} \mathrm{C}$ values between -26.1 to $-23.2 \%$ o (Fig. 8a and Table 1), generally $1-4 \%$ more ${ }^{13} \mathrm{C}$ depleted than bulk POM $(-22.9 \%$ ). Interestingly, alkenones were the most ${ }^{13} \mathrm{C}$-depleted of this group. Overall these "marine" biomarkers had an abundance-weighted average $\delta^{13} \mathrm{C}_{\mathrm{M}}$ of $-25.3 \pm 1.1 \%$ o (Table 4), typical for marine lipids. Radiocarbon values for the marine biomarkers (excluding the highly ${ }^{14} \mathrm{C}$-enriched $18: 1$ fatty acid outlier at $288 \%$ ) ranged from 65 to $146 \%$, giving $\Delta{ }^{14} \mathrm{C}_{\mathrm{M}}$ of $78 \pm 9 \%$, considerably enriched in ${ }^{14} \mathrm{C}$ relative to bulk POM $\left({ }^{14} \mathrm{C}_{\mathrm{OC}}-199 \%\right.$ ) (Fig. 8b). Long-chain even-carbon-number acids and alcohols and odd-carbon-number alkanes had $\delta^{13} \mathrm{C}$ values ranging from -30.1 to $-27.0 \%$, yielding a mean $\delta^{13} \mathrm{C}_{\mathrm{T}}$ of $-28.7 \pm 1.6 \%$, roughly $3 \%$ o depleted in $\delta^{13} \mathrm{C}$ compared to marine lipids. Terrigenous markers had a much greater range of $\Delta^{14} \mathrm{C}$ values $(1 \%$ or for the fatty acids, $-44 \%$ o for the alcohols and $-181 \%$ or the alkanes) but a mean $\Delta{ }^{14} \mathrm{C}_{\mathrm{T}}$ of $-75 \pm 94 \%$. It is possible that some fraction of the long-chain fatty acids are zooplankton (wax ester)-derived young carbon, whereas the long-chain alkanes may contain a relict component. Thus, the long-chain alcohols may represent the best "terrigenous" biomarkers since they would 
have neither modern marine (major alcohols in wax esters are $\mathrm{C}_{16}$ and $\mathrm{C}_{18}$; Wakeham, 1982) nor relict sources with a $\Delta^{14} \mathrm{C}$ of $-1000 \%$. The single sample of "relict" biomarkers isolated by PCGC was a composite of $\mathrm{C}_{24}+\mathrm{C}_{26}+\mathrm{C}_{28} n$ alkanes that had a $\delta^{13} \mathrm{C}_{\mathrm{R}}$ of $-29.1 \pm 0.2 \%$ and a $\Delta{ }^{14} \mathrm{C}_{\mathrm{R}}$ of $-677 \pm 10 \%$; this $\Delta^{14} \mathrm{C}$ value probably also reflects a mix of moderately pre-aged terrigenous $\left(\Delta^{14} \mathrm{C}\right.$ of $-44 \%$ might be reasonable if the alcohols are a good representative of terrigenous OC) and radiocarbon-dead $\left(\Delta^{14} C_{R}\right.$ of -1000) relict carbon.

Marine biomarkers in the $\mathrm{BS}$ sediment had $\delta^{13} \mathrm{C}$ values ranging from -31.9 to $-26.0 \%$ (mean $\delta^{13} \mathrm{C}_{\mathrm{M}}$ $-28.8 \pm 1.8 \%$ ) , about $2.5 \%$ o depleted in ${ }^{13} \mathrm{C}$ relative to both BS bulk SOM $(-25.3 \%$ ) and the marine group of BS POM (also -25.3\%o). Radiocarbon contents of marine biomarkers ranged from -46 to $75 \%$ (mean $\Delta^{14} \mathrm{C}_{\mathrm{M}} 30 \pm 10 \%$, excluding $16: 0$ at $214 \%$ and $18: 0$ at $374 \%$ o), considerably enriched in ${ }^{14} \mathrm{C}$ relative to bulk POM $\left(\Delta^{14} \mathrm{C}_{\mathrm{OC}}-199 \%\right.$ ) but depleted in ${ }^{14} \mathrm{C}$ compared to marine biomarkers in $\mathrm{BS}$ POM. Terrigenous biomarkers displayed $\delta^{13} \mathrm{C}$ values between -31.9 to $-29.7 \%$ (mean $\delta^{13} \mathrm{C}_{\mathrm{T}}-30.5 \pm 0.7 \%$ ). Thus, although there was a considerable overlap in $\delta^{13} \mathrm{C}$ values for marine and terrigenous groups, concentration weighting yielded an offset of $\sim 2 \%$, as would be expected. Plantwax alkanes $\left(\mathrm{C}_{27}\right.$ and $\left.\mathrm{C}_{29}\right)$ and alcohols $\left(\mathrm{C}_{24}\right.$ and $\left.\mathrm{C}_{26}\right)$ were strongly depleted in $\Delta^{14} \mathrm{C}$ relative to the marine lipids (range -231 to $-100 \%$ ), with a mean $\Delta^{14} \mathrm{C}_{\mathrm{T}}$ of $-171 \pm 58 \%$. Long-chain even-carbon-numbered $\left[\mathrm{C}_{24}+\mathrm{C}_{26}+\mathrm{C}_{28}\right]$ alkanes had a $\delta^{13} \mathrm{C}$ value of $-29.2 \%$ and a $\Delta^{14} \mathrm{C}_{\mathrm{R}}$ of $-609 \pm 8 \%$, again suggesting they are pre-aged but not exclusively relict. A similar spread in $\delta^{13} \mathrm{C}$ and $\Delta^{14} \mathrm{C}$ values for marine, vascular-plant and relict-hydrocarbon biomarkers has been previously reported for Black Sea and Arabian Sea sediments (Eglinton et al., 1997).

\subsubsection{Arabian Sea}

The marine biomarkers in the AS trap POM had $\delta^{13} \mathrm{C}$ values between -27.1 and $-16.7 \%$ (mean $\delta^{13} \mathrm{C}_{\mathrm{M}}-23.5 \pm 2.5 \%$ ). ) and $\Delta^{14} \mathrm{C}$ contents ranging from -91 to $111 \%$ (Fig. $9 \mathrm{a}$ and b and Table 2) (mean $\Delta{ }^{14} \mathrm{C}_{\mathrm{M}} 64 \pm 20 \%$ ) , excluding $\mathrm{C}_{14: 0}$ at $178 \%$ and $\mathrm{HBI}$ alkenes at $-514 \%$ ). The negative $\Delta^{14} \mathrm{C}$ value for the HBI alkenes is due to the inclusion of a UCM which could not be removed. The only vascular-plant compounds in the AS trap in sufficient quantity for AMS analysis were analyzed as a composite of $\left[\mathrm{C}_{27}+\mathrm{C}_{29}\right] n$-alkanes, giving a $\delta^{13} \mathrm{C}_{\mathrm{T}}$ of $-28.4 \%$ and a $\Delta^{14} \mathrm{C}_{\mathrm{T}}$ of $-320 \pm 24 \%$ o. The single sample of $\left[\mathrm{C}_{24}+\mathrm{C}_{26}+\mathrm{C}_{28}\right] n$-alkanes gave a $\delta^{13} \mathrm{C}_{\mathrm{R}}$ of $-28.5 \pm 0.2 \%$ and a $\Delta^{14} \mathrm{C}_{\mathrm{R}}$ of $-731 \pm 14 \%$.

The $\delta^{13} \mathrm{C}$ values for marine biomarkers in $\mathrm{AS}$ sediments ranged from -26.8 to $-18.2 \%\left(\delta^{13} \mathrm{C}_{\mathrm{M}}\right.$ mean $-24.5 \pm 2.1 \%$ ) , and $\Delta^{14} \mathrm{C}$ ranged from 104 to $-171 \%$ o $\left(\Delta^{14} \mathrm{C}_{\mathrm{M}}-63 \pm 10 \%\right.$, excluding $18: 0 \mathrm{FA}$ at $190 \%$ and HBI alkenes at $-256 \%$ ). Vascular-plant $\left[\mathrm{C}_{26}+\mathrm{C}_{28}+\mathrm{C}_{30}\right] n$ alcohols had a $\delta^{13} \mathrm{C}$ value of $-24.1 \%$ and a $\Delta^{14} \mathrm{C}$ value of

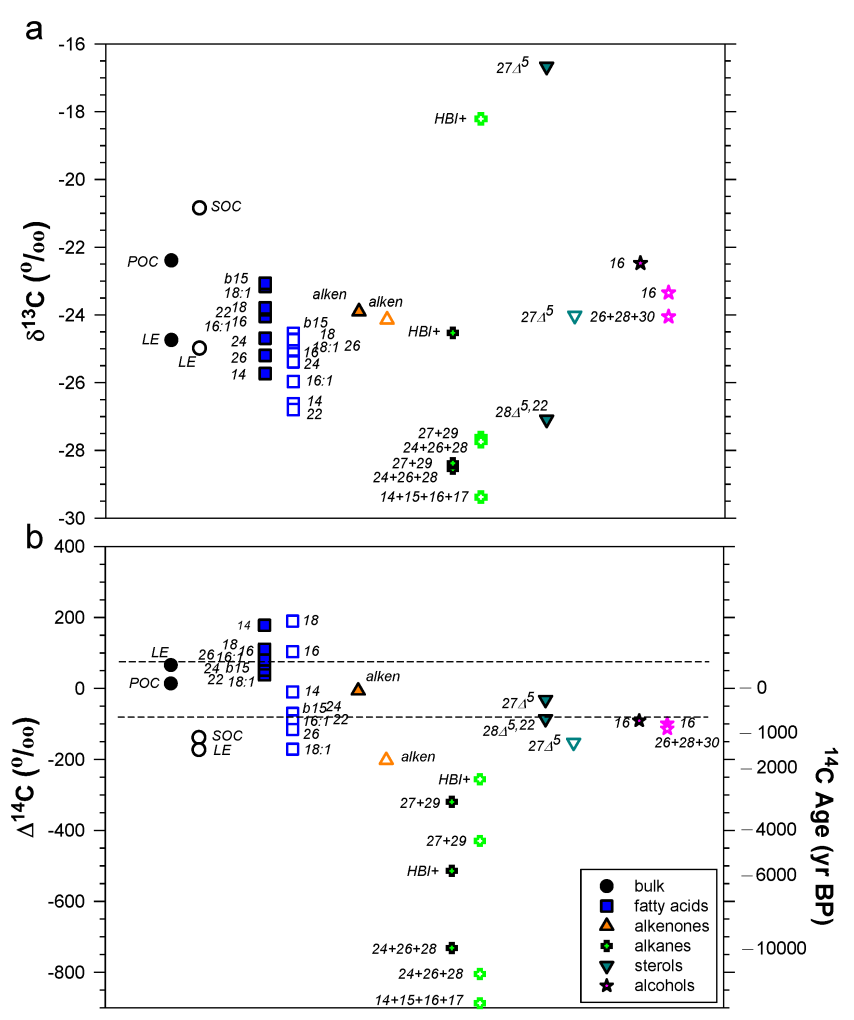

Figure 9. The (a) $\delta^{13} \mathrm{C}$ and (b) $\Delta^{14} \mathrm{C}$ values of bulk POC and SOC and individual biomarkers for trap and sediments from the Arabian Sea (see also Table 2). Filled symbols are trap biomarkers; open symbols are sediment biomarkers. All values have been corrected for procedural blanks and any derivative carbon, as needed. Dashed lines are pre-bomb (lower) and post-bomb (upper) mixedlayer $\Delta^{14} \mathrm{C}_{\mathrm{DIC}}$.

$-113 \pm 13 \%$, and $\left[\mathrm{C}_{27}+\mathrm{C}_{29}\right] n$-alkanes displayed a $\delta^{13} \mathrm{C}$ value of $-27.7 \%$ and a $\Delta^{14} \mathrm{C}$ value of $-430 \pm 11 \%$. Together, the terrigenous biomarkers had a concentrationweighted $\delta^{13} \mathrm{C}_{\mathrm{T}}$ value of $-27.7 \pm 0.20 \%$ and a $\Delta{ }^{14} \mathrm{C}_{\mathrm{T}}$ of $-430 \pm 30 \%$. Two groups of $n$-alkanes in AS sediments could be assigned to relict sources. Short-chain $\left[\mathrm{C}_{14}+\mathrm{C}_{15}+\mathrm{C}_{16}+\mathrm{C}_{17}\right]$ alkanes and the UCM under this group of homologs had a $\delta^{13} \mathrm{C}$ value of $-29.4 \%$ and a $\Delta{ }^{14} \mathrm{C}$ value of $-887 \pm 5 \%$. Long-chain $\left[\mathrm{C}_{24}+\mathrm{C}_{26}+\mathrm{C}_{28}\right] n$ alkanes had a $\delta^{13} \mathrm{C}$ value of $-27.6 \%$ and a $\Delta^{14} \mathrm{C}$ value of $-805 \pm 9 \%$. Thus, $\delta^{13} \mathrm{C}_{\mathrm{R}}$ and $\Delta^{14} \mathrm{C}_{\mathrm{R}}$ for the AS sediments would be $-28.5 \pm 1.2$ and $-846 \pm 58 \%$, respectively.

\subsubsection{Ross Sea}

Ross Sea POM and SOM contained only fatty acids and alcohols/sterols in sufficient abundance for compound-specific isotopic analysis. In keeping with a ${ }^{13} \mathrm{C}$ isotope depletion in high-latitude regions, noted above, fatty acids had $\delta^{13} \mathrm{C}$ values ranging from -35.3 to $-31.7 \%$ and alcohol/sterol values ranging from -35.4 to $-31.8 \%$ (Fig. 10a and Table 3), together giving a mean $\delta^{13} \mathrm{C}_{\mathrm{M}}$ of $-33.2 \pm 1.8 \%$. 
Table 4. Abundance-weighted mean table carbon and radiocarbon isotope values for composited marine, terrigenous and relict biomarkers.

\begin{tabular}{|c|c|c|c|c|c|}
\hline & $\delta^{13} \mathrm{C}(\% o) \pm$ s.d. & $\Delta^{14} \mathrm{C}(\% \circ) \pm$ s.d. & $f_{\mathrm{m}} \pm$ s.d. & Age \pm s.d. & $n$ \\
\hline \multicolumn{6}{|c|}{ BS trap } \\
\hline Marine & $-25.3 \pm 1.1$ & $78 \pm 9$ & $1.110 \pm 0.066$ & $>$ Mod & 7 \\
\hline Terrigenous & $-28.7 \pm 1.6$ & $-75 \pm 94$ & $0.930 \pm 0.043$ & $580 \pm 360$ & 3 \\
\hline Relict & -29.1 & $-677 \pm 10$ & $0.325 \pm 0.009$ & $9030 \pm 220$ & 1 \\
\hline \multicolumn{6}{|c|}{ BS sediment } \\
\hline Marine & $-28.8 \pm 1.8$ & $-30 \pm 10$ & $0.970 \pm 0.023$ & $240 \pm 56$ & 6 \\
\hline Terrigenous & $-30.5 \pm 0.7$ & $-171 \pm 58$ & $0.833 \pm 0.066$ & $1470 \pm 615$ & 5 \\
\hline Relict & -29.2 & $-609 \pm 8$ & $0.393 \pm 0.007$ & $7500 \pm 150$ & 1 \\
\hline \multicolumn{6}{|c|}{ AS trap } \\
\hline Marine & $-23.5 \pm 2.5$ & $64 \pm 20$ & $1.071 \pm 0.019$ & $>$ Mod & 7 \\
\hline Terrigenous & $-26.8 \pm 2.3$ & $-320 \pm 24$ & $0.684 \pm 0.024$ & $3050 \pm 280$ & 1 \\
\hline Relict & -28.5 & $-731 \pm 14$ & $0.270 \pm 0.013$ & $10140 \pm 360$ & 1 \\
\hline \multicolumn{6}{|c|}{ AS sediment } \\
\hline Marine & $-24.5 \pm 2.1$ & $-63 \pm 110$ & $0.941 \pm 0.110$ & $490 \pm 1440$ & 8 \\
\hline Terrigenous & $-27.7 \pm 0.02$ & $-430 \pm 30$ & $0.573 \pm 0.011$ & $4470 \pm 150$ & 2 \\
\hline Relict & $-28.5 \pm 1.2$ & $-846 \pm 58$ & $0.114 \pm 0.004$ & $17440 \pm 270$ & 2 \\
\hline \multicolumn{6}{|c|}{ RS trap } \\
\hline Marine & $-33.2 \pm 1.8$ & $-155 \pm 47$ & $0.850 \pm 0.045$ & $1310 \pm 420$ & 7 \\
\hline Terrigenous & $\mathrm{nd}^{*}$ & $\mathrm{nd}^{*}$ & $\mathrm{nd}^{*}$ & $\mathrm{nd}^{*}$ & $\mathrm{nd}^{*}$ \\
\hline Relict & $\mathrm{nd}^{*}$ & $\mathrm{nd}^{*}$ & $\mathrm{nd}^{*}$ & $\mathrm{nd}^{*}$ & $\mathrm{nd}^{*}$ \\
\hline \multicolumn{6}{|c|}{ RS sediment } \\
\hline Marine & $-33.2 \pm 1.9$ & $-105 \pm 31$ & $0.900 \pm 0.030$ & $850 \pm 270$ & 6 \\
\hline Terrigenous & $-31.8 \pm 2.8$ & $-255 \pm 66$ & $0.750 \pm 0.056$ & $2310 \pm 560$ & 2 \\
\hline Relict & $\mathrm{nd}^{*}$ & $\mathrm{nd}^{*}$ & $\mathrm{nd}^{*}$ & $\mathrm{nd}^{*}$ & $\mathrm{nd}^{*}$ \\
\hline
\end{tabular}

* nd stands for not determined

Radiocarbon contents ranged from -216 to $-100 \%$, with the alcohols/sterols slightly depleted relative to the fatty acids, for a $\Delta^{14} \mathrm{C}_{\mathrm{M}}$ of $-155 \pm 47 \%$ (Fig. 10b).

Fatty acids and sterols/alcohols in RS sediments had $\delta^{13} \mathrm{C}$ values ranging from -36.6 to -31.7 and -34.3 to $-33.0 \%$, respectively, for a mean $\delta^{13} \mathrm{C}_{\mathrm{M}}$ of $-33.2 \pm 1.9 \%$. Radiocarbon contents of fatty acids from RS sediments were more variable than for RS POM, with values ranging from -302 to $-83 \%$. Sterols from RS sediments were very unchanged from sterols in POM with $\Delta^{14} \mathrm{C}$ values between -202 and $-178 \%$ for sterols. Overall, this gave a mean $\Delta^{14} \mathrm{C}_{\mathrm{M}}$ of $-105 \pm 31 \%$ o, also essentially the same as for $\Delta^{14} \mathrm{C}_{M}$ of the trap material. The two vascular plant FAs (24:0 and $26: 0)$ gave a $\delta^{13} \mathrm{C}_{\mathrm{T}}$ value of $31.8 \pm 0.28 \%$ and a $\Delta^{14} \mathrm{C}_{\mathrm{T}}$ value of $255 \pm 66 \%$.

\subsection{The provenance of POM and SOM in the Black Sea and Arabian Sea}

Concentration-weighted isotope values (Table 4) can be used to constrain the ranges of isotopic compositions of marine, terrigenous and relict biomarkers and, by extension, organic carbon, of Black Sea and Arabian Sea POM and SOM. Few biomarkers could be isolated from the Ross Sea in sufficient quantities for AMS analyses. Overall, $\delta^{13} \mathrm{C}_{\mathrm{M}}>\delta^{13} \mathrm{C}_{\mathrm{T}}$ $\sim \delta^{13} \mathrm{C}_{\mathrm{R}}$ and $\Delta^{14} \mathrm{C}_{\mathrm{M}}>\Delta{ }^{14} \mathrm{C}_{\mathrm{T}} \gg \Delta^{14} \mathrm{C}_{\mathrm{R}}$ (Fig. 11). Furthermore, SOM biomarkers were generally ${ }^{13} \mathrm{C}$-depleted and ${ }^{14} \mathrm{C}$-depleted relative to their corresponding POM samples, indicative of higher proportions of ${ }^{13} \mathrm{C}$-depleted but older, pre-aged OC in sediments. The range of $\delta^{13} \mathrm{C}_{\mathrm{R}}$ was relatively small compared to $\delta^{13} \mathrm{C}_{\mathrm{M}}$ and $\delta^{13} \mathrm{C}_{\mathrm{T}}$ of POM and SOM, but the span of $\Delta^{14} C_{R}$ values was quite large since the oddcarbon-number hydrocarbons constituting these groups are a 
Table 5. Isotopic values used in mass balance calculations. The values of $f_{\mathrm{M}}, f_{\mathrm{T}}$ and $f_{\mathrm{R}}$ are those values calculated assuming that the actual value of $\Delta^{14} \mathrm{C}_{\text {added }}$ is that measured on the compounds defined as relict.

\begin{tabular}{cccccccc}
\hline Sample & $\Delta^{14} \mathrm{C}_{\text {bulk }}(\%)$ & $\Delta{ }^{14} \mathrm{C}_{\mathrm{M}}(\%)$ & $\Delta^{14} \mathrm{C}_{\mathrm{T}}(\%)$ & $\Delta{ }^{14} \mathrm{C}_{\text {add }}(\% o)$ & $f_{\mathrm{M}}$ & $f_{\mathrm{T}}$ & $f_{\mathrm{R}}$ \\
\hline BS trap & -100 & 80 & -75 & -677 & 0.76 & 0.08 & 0.15 \\
BS sed & -150 & -30 & -171 & -609 & 0.79 & 0.1 & 0.11 \\
AS trap & 64 & 64 & -320 & -731 & 1 & 0 & 0 \\
AS sed & -173 & -63 & -430 & -846 & 0.86 & 0.04 & 0.1 \\
RS sed & -210 & -105 & -255 & - & - & - & - \\
\hline
\end{tabular}

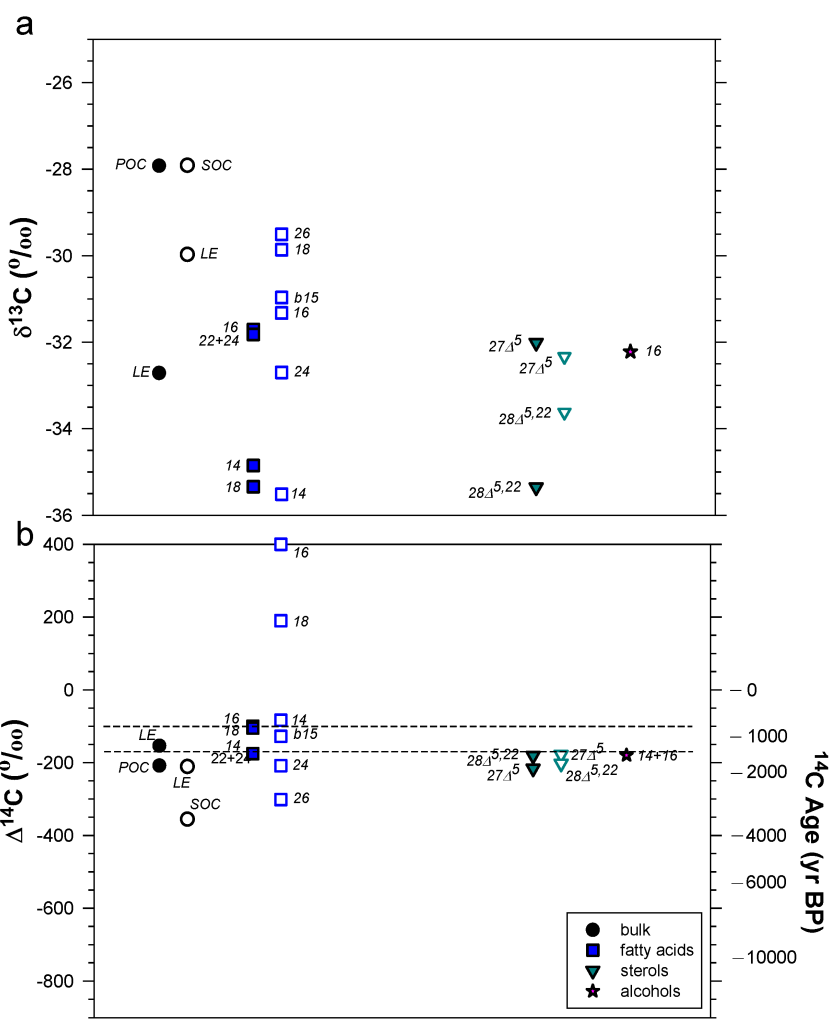

Figure 10. The (a) $\delta^{13} \mathrm{C}$ and (b) $\Delta^{14} \mathrm{C}$ values of bulk POC and SOC and individual biomarkers for trap and sediments from the Ross Sea (see also Table 3). Filled symbols are trap biomarkers; open symbols are sediment biomarkers. All values have been corrected for procedural blanks and any derivative carbon, as needed. Dashed lines are pre-bomb (lower) and post-bomb (upper) mixedlayer $\Delta^{14} \mathrm{C}_{\mathrm{DIC}}$.

mix of old but not radiocarbon-"dead" terrigenous vascularplant $\left(\Delta^{14} \mathrm{C}\right.$ values similar to average $\Delta^{14} \mathrm{C}_{\mathrm{T}}$ values) and truly relict $\left(\Delta^{14} \mathrm{C}=1000 \%\right.$ o $\mathrm{OC}$.

The relative contributions of marine, pre-aged terrigenous and relict $\mathrm{OC}\left(f_{\mathrm{M}}, f_{\mathrm{T}}\right.$, and $\left.f_{\mathrm{R}}\right)$ to sediment trap material and sediments can be estimated in the Black, Arabian and Ross Seas using an isotopic mass balance. Plots of $\delta^{13} \mathrm{C}_{\mathrm{M}, \mathrm{T}, \mathrm{R}}$ vs. $\Delta^{14} \mathrm{C}_{\mathrm{M}, \mathrm{T}, \mathrm{R}}$ in both the sediment traps and sediment (Fig. 11) show significantly different values for the radiocarbon content of the different carbon pools but relatively small differ-
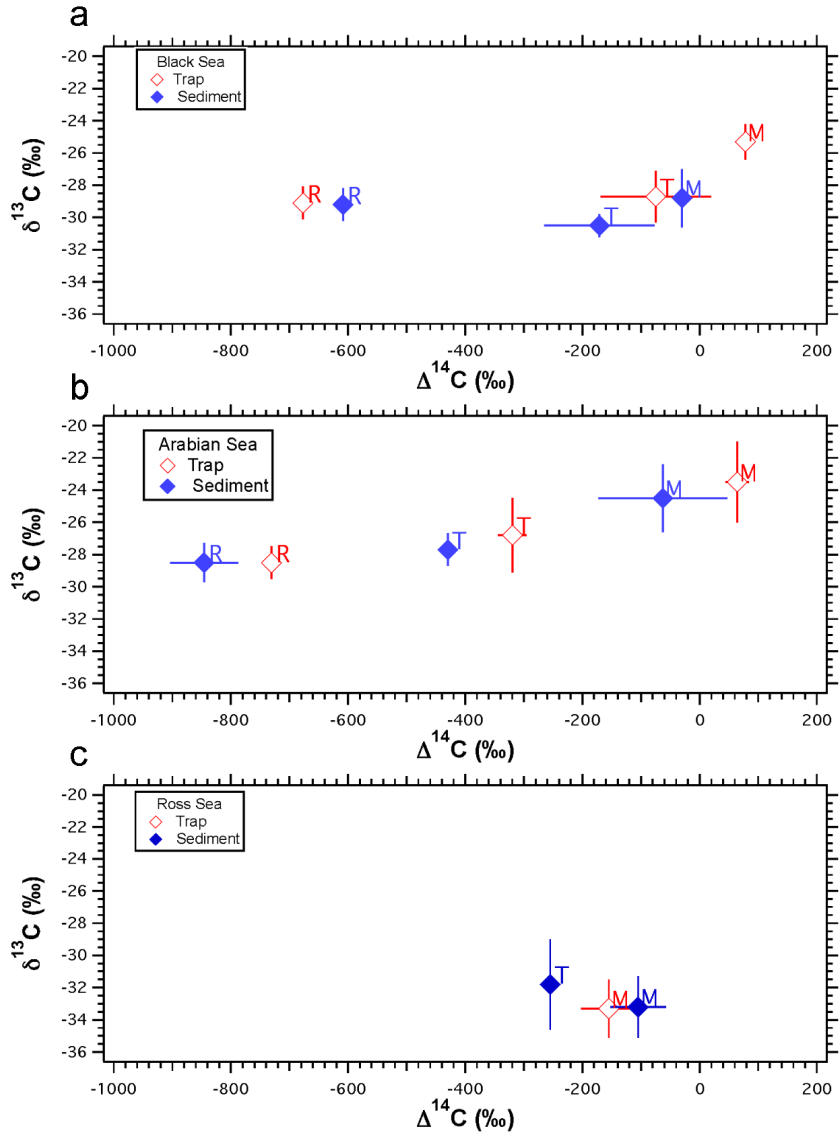

Figure 11. Concentration-weighted average $\delta^{13} \mathrm{C}$ and $\Delta^{14} \mathrm{C}$ values of marine (M), terrigenous (T) and relict (R) lipids in (a) Black Sea, (b) Arabian Sea and (c) Ross Sea traps and sediments.

ences in the stable isotopic content in the Black and Arabian seas and in the Ross Sea sediments. The small differences in $\delta^{13} \mathrm{C}$ coupled with significant error make it difficult to use the stable isotopic composition as a discriminating factor in determining the sources of the bulk material. However, the large differences observed in the $\Delta^{14} \mathrm{C}$ values make it possible to use these data to constrain the relative amounts of relict, terrestrial and marine components.

For each sample, there is a $\Delta{ }^{14} \mathrm{C}$ value assigned to the bulk SLE, fresh marine material, fresh terrestrial material 
and a relict-terrestrial mix. Bulk material is assumed to be a mixture of fresh marine and other "added" material, where the added material refers to the fresh terrestrial and relictterrestrial mix. Given this, we can derive the relative amounts of marine and "added" material.

$1=f_{\mathrm{M}}+f_{\text {added }}$

$\Delta{ }^{14} \mathrm{C}_{\text {bulk }}=f_{\mathrm{M}}\left(\Delta^{14} \mathrm{C}_{\mathrm{mar}}\right)+f_{\text {added }}\left(\Delta^{14} \mathrm{C}_{\text {added }}\right)$,

solving this equation for $f_{\text {added }}$ as follows:

$f_{\text {added }}=\frac{\Delta^{14} C_{\text {bulk }}-\Delta^{14} C_{M}}{\Delta^{14} C_{\text {added }}-\Delta^{14} C_{M}}$.

The value of $\Delta^{14} \mathrm{C}_{\mathrm{added}}$ can range from that for relict material $(-1000 \%)$ to that of the bulk material. Using this information, we can calculate the relative amounts of marine and "added" material as a function of the $\Delta^{14} \mathrm{C}$ of the "added" material. Further, we can combine the radiocarbon value measured on the terrestrial portion with the value of truly relict material to calculate how much of the "added" material might come from fresh terrestrial material using the equations below.

$$
\begin{aligned}
& f_{\text {added }}=f_{\mathrm{T}}+f_{\mathrm{R}} \\
& \Delta{ }^{14} \mathrm{C}_{\text {added }}=f_{\mathrm{T}}\left(\Delta^{14} \mathrm{C}_{\mathrm{T}}\right)+f_{\mathrm{R}}\left(\Delta^{14} \mathrm{C}_{\mathrm{R}}\right)
\end{aligned}
$$

Truly relict material has a $\Delta{ }^{14} \mathrm{C}$ value of $-1000 \%$, and fresh terrigenous material has the values determined in this study $\left(\Delta^{14} \mathrm{C}_{\mathrm{T}}\right.$, Table 5). As stated earlier, the measured value of $\Delta^{14} C_{R}$ appears to be a mixture of truly relict material and terrigenous material with a suite of ages. If we assume that the value we measured for "relict" material (Table 5) is a good representation of $\Delta{ }^{14} C_{\text {added }}$, then we have a unique solution to the mass balance. This solution is indicated by the vertical lines in Fig. 12 and the values listed in Table 5. Using this model, we force ourselves to an extreme situation where all the "added" material is either vascular or totally dead. Thus, the relative fractions of terrestrial and relict material must be considered maximum and minimum values, respectively.

For the calculations, concentration-weighted $\delta^{13} \mathrm{C}_{\mathrm{M}}$, $\delta^{13} \mathrm{C}_{\mathrm{T}}, \delta^{13} \mathrm{C}_{R}, \delta{ }^{13} \mathrm{C}_{\mathrm{B}}, \Delta{ }^{14} \mathrm{C}_{\mathrm{M}}, \Delta{ }^{14} \mathrm{C}_{\mathrm{T}}$ and $\Delta{ }^{14} \mathrm{C}_{\mathrm{B}}$ values listed in Table 4 were used. The relative fractions of marine, terrestrial and relict material $\left(f_{\mathrm{M}}, f_{\mathrm{T}}\right.$, and $\left.f_{\mathrm{R}}\right)$ as a function of $\Delta^{14} C_{\text {added }}$ are shown in Fig. 12. It is most likely that the marine component is dominant in both the trap and sediment samples, although the possible values range from $>80$ to $0 \%$. Fresh vascular material can account for 0 up to almost $100 \%$. The amount of relict material is constant at a low proportion, ranging from 0 to $<20 \%$ in both the trap and sediments. In the AS, the marine component is dominant in both the trap and sediments; the trap data indicate that there can be virtually no relict or vascular material input to this sample, while the sediment data suggest that up to $30 \%$ of the material may come from either relict or vascular sources. In the RS sediment, marine material dominates in almost all instances, with possible values ranging from 90 to $30 \%$. Relict material can account for $>10$ to $0 \%$ and vascular from 0 to $<70 \%$.

In the Black Sea and Arabian Sea cases here, it is likely that the marine component contributes the most material because a marine biogenic flux dominates at both sites. No comparable combined biomarker, ${ }^{13} \mathrm{C}$ and ${ }^{14} \mathrm{C}$ studies of $\mathrm{POM}$ at other sites exist to our knowledge. But the high amounts of marine OC in the Black Sea and Arabian Sea sediments contrasts with other environments where similar biomarker-isotopic mass balances have been made, although using a narrower range of biomarkers. In nearshore sediments on the northern California Margin off the high-energy Eel River that erodes ancient sedimentary rocks in its watershed (Blair et al., 2003), fractional contributions from marine, terrestrial and relict components were estimated at 0 $10,50-75$ and $30-50 \%$ of total OC (Drenzek et al., 2009). On the Washington Margin off the lower-energy Columbia River, marine, terrestrial and relict OC contribute 2, 89-95 and $3-9 \%$ of bulk sedimentary OC (Feng et al., 2013). Sediments in the Beaufort Sea had $f_{\mathrm{M}}, f_{\mathrm{T}}$ and $f_{\mathrm{R}}$ values of $13-27,36-42$ and 34-37\%, respectively, with the elevated $f_{\mathrm{R}}$ values consistent with the well-defined petrogenic signature of $n$-alkanes and polycyclic aromatic hydrocarbons in Mackenzie River and Beaufort Sea sediments (Yunker et al., 1993, 2002). For surface sediments in the southwest Black Sea near our study site, Kusch et al. (2010) estimate an $f_{\mathrm{R}}$ of $\sim 18 \%$ of OC. In the Santa Monica Basin of the California Borderlands, $80-87 \%$ of the $n$-alkanes were of terrigenous plant origin, whereas up to $20 \%$ of the alkanes were derived from petroleum or shales (Pearson and Eglinton, 2000), but since alkanes are not abundant in most marine biota, no estimation of the marine component was made.

For the Black Sea, the graphs for the relative contributions look similar for both the trap and sediment samples. A strict interpretation of these results suggests that there is a greater relative amount of nonmarine material in the sediment trap than in the sediments themselves. Given the limitations of our data set, we believe that it is more likely that the relative amounts of material are actually very similar. This is somewhat surprising for two reasons. First, under a differential degradation/preservation case (Wakeham and Canuel, 2006), a more labile component of marine OC would be selectively degraded as POM moved between the trap depths and the surface sediments, leaving behind increased proportions of selectively preserved, more refractory terrigenous and relict components in sediments. Alternately, lateral advection of terrigenous and relict $\mathrm{OC}$ below the trap depths either by mid-depth or bottom currents might simply allow this pre-aged material to bypass the traps to be deposited directly on the sediments. At the Black Sea site, 
advective transport of continental material containing terrigenous and relict carbon to the study site is likely via surface, mid-water $(\sim 150 \mathrm{~m}$ depth) or bottom-water nepheloid layers and turbidites. Surface and mid-water plumes moving offshore could carry some continental material to the shallow $(\sim 250 \mathrm{~m})$ sediment trap. But a greater amount of terrigenous and relict carbon might, after temporary storage on the narrow continental shelf, be remobilized to move laterally down the steep continental slope under the trap. This type of advective remobilization of pre-aged material is well documented at other locations for both marine-derived alkenones (e.g., Ohkouchi et al., 2002; Mollenhauer et al., 2003) and terrigenous/relict OC (e.g., Aller et al., 2004; Mead and Goñi, 2006; Mollenhauer and Eglinton, 2007; Kusch et al., 2010; Hwang et al., 2010). Aeolian transport of leaf wax OC and petrogenic OC to the sediments of the central Black Sea have been reported (Wakeham 1996; Eglinton et al., 1997), but the importance of aeolian delivery to the southwestern Black Sea is unknown. Nonetheless, a small leaf wax/petrogenic signal was detected in the trap POM. Because the trap was already deployed within the anoxic zone (which starts at 120-150 m), OC degradation in the water column and surface sediments should be depressed, so that degradation might not be a significant cause for any reduction in $f_{\mathrm{M}}$ in the sediments.

In the Arabian Sea, the sediment trap material indicates that the material is all marine while the sediments show a small influence of nonmarine material. The Arabian Sea site was in an area of intense upwelling dominated by high export of diatomaceous material (Wakeham et al., 2002), remote from fluvial inputs but potentially affected by aeolian transport of pre-aged OC off the Arabian Peninsula and Horn of Africa during the windy monsoon periods (Dahl et al., 2005). The AS trap was deployed within the OMZ where organic matter degradation has reduced dissolved oxygen concentrations to $\sim 5 \mu \mathrm{M}$ (Smith et al., 1998), but AS sediments were collected at $1400 \mathrm{~m}$ water depth where bottom waters are oxygenated. Indeed within and below the OMZ, OC fluxes decreased 5-10 fold between the trap and surface sediments, even as \% OC did not change as dramatically (Lee et al., 2000 for OC; Wakeham et al., 2002 for AS lipid fluxes). Comparative studies have shown conclusively that, among other things (e.g., intrinsic reactivity of organic molecules and protection by macromolecular organic matrices and mineral surfaces), oxygen availability is a key control on OC and lipid degradation/preservation in water columns and sediments (e.g., Hedges and Keil, 1995; Gong and Hollander, 1997; Wakeham and Canuel, 2006; Burdige, 2007; Mollenhauer and Eglinton, 2007). Enhanced degradation (diminished preservation) in the oxygenated AS should be greater than in the anoxic Black Sea, and if marine OC is more labile than terrigenous/relict OC, $f_{\mathrm{M}}$ in the AS POM and SOM would, as observed, be higher than in the BS. The extensive production of petroleum reserves on the Arabian Peninsula and intense tanker traffic in the Arabian Sea is an
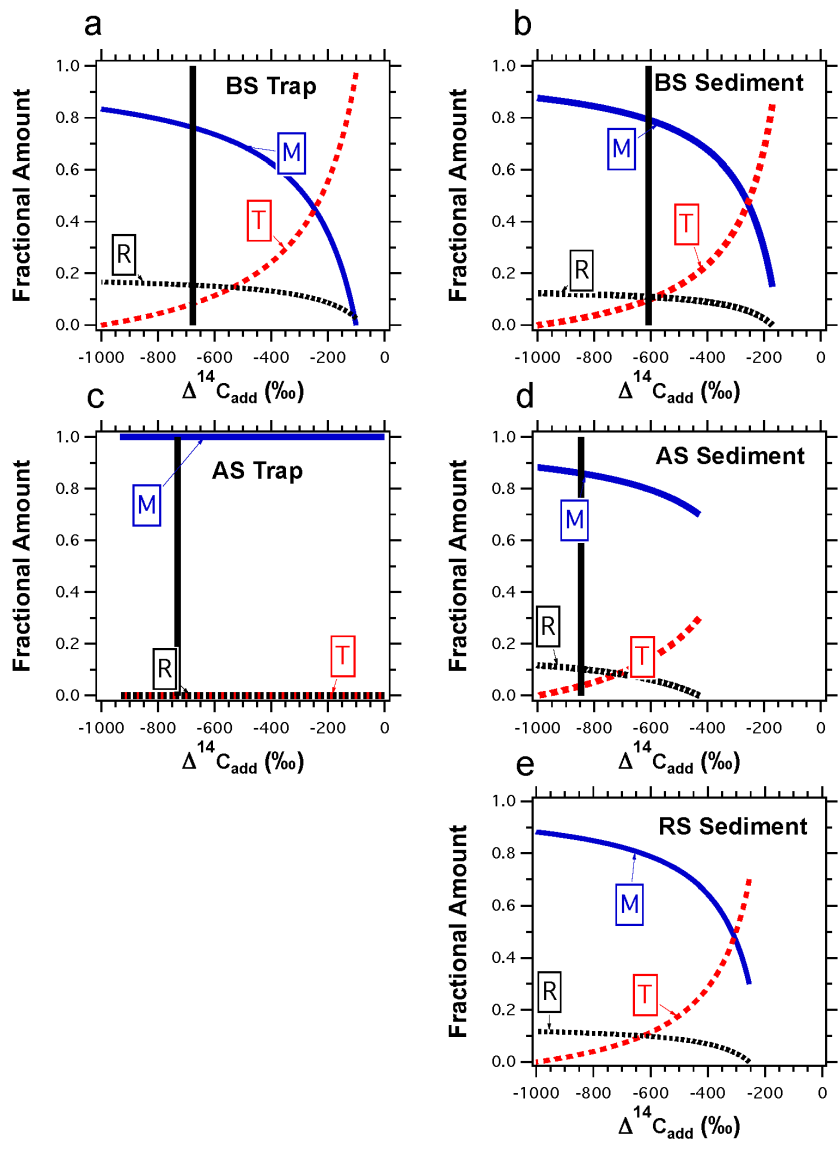

Figure 12. Relative amounts of marine (M, blue solid line), terrestrial ( $\mathrm{T}$, red dashed line) and relict ( $\mathrm{R}$, black dashed line) carbon as a function of $\Delta^{14} C_{\text {added }}$ in Black Sea and Arabian Sea trap material (a and c, respectively) and in Black Sea, Arabian Sea and Ross Sea sediments (b, d, and e, respectively). Only real solutions are depicted. The solid black line indicates the solution when $\Delta^{14} C_{\text {added }}$ is equal to the value measured on compounds defined as relict. There are not enough data to construct a graph for the Ross Sea sediment trap.

additional source of refractory and radiocarbon-dead petrogenic OC to AS particulate matter and sediments.

The RS sediment results are consistent with previous studies suggesting that marine material is the most important source of organic matter in the sediments (Arrigo et al., 2002; Dunbar et al., 2003). The solutions that suggest a relatively large input of vascular-plant material seem unrealistic given these prior studies. The Ross Sea data set is very limited and in fact does not include unambiguous lipids of either terrestrial or relict origins with which to constrain the isotopic compositions of these endmembers.

\section{Conclusions}

This study examined the compound-specific ${ }^{13} \mathrm{C}$ and ${ }^{14} \mathrm{C}$ compositions of diverse biomarker indicators of marine 
biomass, terrigenous vascular-plant and relict sources of organic carbon in sediment traps and underlying surface sediments in the Black Sea the Arabian Sea and the Ross Sea. Using an isotopic mass balance approach, it was possible to constrain relative inputs from these three sources, with marine biomass accounting for 66-100\% of extractable lipids and organic carbon in Black Sea and Arabian Sea sediment trap material. The remaining 3-8\% derive from terrigenous and $4-16 \%$ from relict sources. Sediments contained lower proportions of marine biomarkers (66-90\%) and consequentially higher proportions of terrigenous and relict carbon (317 and $7-13 \%$, respectively). These results suggest that although particulate organic carbon is overwhelmingly marine in origin, there are significant proportions of pre-aged terrigenous and relict $\mathrm{OC}$ present. Because these latter fractions become proportionally more important in sediments, it is likely that they are better preserved than the marine component and/or that they reach the sediments by lateral advection rather than only by the vertical sinking that affects the upper ocean-derived marine POC. This approach demonstrates the strengths, and limitations, of such a multiparameter approach for studying marine OC cycling and budgeting.

Acknowledgements. We thank Susumo Honjo and Steve Manganini for providing the Black Sea sediment trap material, Rob Dunbar for the Ross Sea trap material, and Tim Eglinton, Nao Ohkouchi and Jacqueline Grebmeier for providing the Ross Sea sediments. Michael Peterson helped with sediment trap and sediment collections in the Arabian Sea. Tamara Pease helped with initial analytical workup. NOSAMS personnel are thanked for assistance in sample processing there for ${ }^{13} \mathrm{C}$ and ${ }^{14} \mathrm{C}$ analyses. Grants OCE-9310364 and OCE-9911678 from the US National Science Foundation (NSF) and the NSF Cooperative Agreement for the Operation of a National Ocean Sciences Accelerator Mass Spectrometry Facility (OCE-0753487 and OCE-123966) supported this research. S. G. Wakeham acknowledges the Hanse Wissenschaftskolleg (Hanse Institute for Advanced Studies), Delmenhorst, Germany, for a fellowship that supported the writing of this manuscript.

Edited by: X. Wang

\section{References}

Aller, R. C.: Bioturbation and remineralization of sedimentary organic matter: effects of redox oscillation, Chem. Geol., 114, 331345,1994

Anderson, J. B., Brake, C., and Myers, N.: Sedimentation on the Ross Sea continental shelf, Mar. Geol., 57, 295-333, 1984.

Andrews, J. T., Domack, E. W., Cunningham, W. L., Leventer, A., Licht, K. J., Jull, A. J. T., DeMaster, D. J., and Jennings, A. E.: Problems and possible solutions concerning radiocarbon dating of surface marine sediments, Ross Sea, Antarctica, Quat. Res., 52, 206-216, 1999.

Arrigo, K. R., DiTullio, G. R., Dunbar, R. B., Lizotte, M. P., Robinson, D. R., Van Woert, M., and Worthen, D. L.: Phytoplankton taxonomic variability and nutrient utilization and primary production in the Ross Sea, J. Geophys. Res., 105, 8827-8846, 2000.
Arthur M. A. and Dean W. E.: Organic-matter production and preservation and evolution of anoxia in the Holocene Black Sea, Paleoceanogr., 13, 395-411, 1998.

Belt, S. T., Allard, W. G., Massé, Robert, J.-M., and Rowland, S. J.: Highly branched isoprenoids (HBIs): Identification of the most common and abundant sedimentary isomers. Geochim. Cosmochim. Ac., 64, 3829-3851, 2000.

Bentley, P. N.: Characteristics and distribution of wind blown sediment, western McMurdo Sound, Antarctica, Thesis, Victoria Univ. Wellington, N.Z. 46 pp., 1979.

Berkman, P. A. and Forman, S. L.: Pre-bomb radiocarbon and the reservoir correction for calcareous marine species in the Southern Ocean, Geophys. Res. Lett., 23, 363-66, 1996.

Berner, R. A.: Burial of organic carbon and pyrite sulfur in the modern ocean - its geochemical and environmental significance, Am. J. Sci., 282, 451-473, 1982.

Blair, N. E., Leithold, E. L., Ford, S. T., Peeler, K. A., Holmes, J. C., and Perkey, D. W.: The persistence of memory: the fate of ancient sedimentary organic carbon in a modern sedimentary system, Geochim. Cosmochim. Ac., 67, 63-73, 2003.

Burdige, D. J.: Burial of terrestrial organic matter in marine sediments: A re-assessment, Global Biogeochem. Cycles, 19, GB4011, doi:10.1029/2004GB002368, 2001.

Burdige, D. J.: Preservation of organic matter in marine sediments: controls, mechanisms, and an imbalance in sediment organic carbon budgets? Chem. Rev., 107, 467-485, 2007.

Burkins, M. B., Virginia, R. A., Chamberlain, R. A., and Wall, D. H.: The origin of soil organic matter in Taylor Valley, Antarctica, Antarct. Ecol., 81, 2377-2391, 2000.

Chikaraishi, Y., Naraoka, H., and Poulson, S. R.: Hydrogen and carbon isotopic fractionations of lipid biosynthesis amount terrestrial (C3, C4, and CAM) and aquatic plants, Phytochem., 65, 1369-1381, 2004.

Collister, J. W., Rieley, G., Stern, B., Eglinton, G., and Fry, B.: Compound-specific ${ }^{13} \mathrm{C}$ analyses of leaf lipids from plants with differing carbon dioxide metabolisms, Org. Geochem., 21, 619627, 1994.

Conte, M. H. and Weber, J. C.: Plant biomarkers in aerosols record isotopic discrimination of terrestrial photosynthesis, Nature, 417 , 639-641, 2002.

Cowie, G. L. and Hedges, J. I.: Biochemical indicators of diagenetic alteration in natural organic mixtures, Nature, 369, 304307, 1994.

Dahl, K. A., Oppo, D. W., Eglinton, T. I., Hughen, K. A., Curry W. B., and Sirocko, F.: Terrigenous plant wax inputs to the Arabian Sea: Implications for the reconstruction of winds associated with the Indian Monsoon, Geochim. Cosmochim. Ac., 10, 2547 2558, 2005.

Dehairs, F., Kopczynska, E., Nielsen, P., Lancelot, C., Bakker, D. C. E., Koeve, W., and Goyens, L.: $\delta^{13} \mathrm{C}$ of Southern Ocean suspended organic matter during spring and early summer: Regional and temporal variability, Deep-Sea Res., Part II, 44, 129-142, 1997.

DeMaster, D. J., Ragueneau, O., and Nittrouer, C. A.: Preservation efficiencies and accumulation rates for biogenic silica and organic C, N, and P in high-latitude sediments: the Ross Sea, J. Geophys. Res., 101, 18501-18518, 1996.

Domack, E. W., Jull, A. J. T., Anderson, J. B., Linick, T. W., and Williams, C. R.: Application of tandem accelerator mass- 
spectrometer dating to Late-Pleistocene-Holocene sediments of the East Antarctic continental shelf, Quaternary Res., 31, 277287, 1989.

Drenzek, N. J., Montluçon, D. B., Yunker, M. B., Macdonald, R. W., and Eglinton, T. I.: Constraints on the origin of sedimentary organic carbon in the Beaufort Sea from coupled molecular ${ }^{14} \mathrm{C}$ and ${ }^{13} \mathrm{C}$ measurements, Mar. Chem., 103, 146-162, 2007.

Drenzek, N. J., Hughen, K. A., Montluçon, D. B., Southon, J. R., dos Santos, G. M., Druffel, E. R. M., Giosan, L., and Eglinton, T. I.: A new look at old carbon in active margin sediments, Geology, 37, 239-242, 2009.

Druffel, E. R. M., Bauer, J. E., Williams, P. M., Griffin, S., and Wolgast, D.: Seasonal variability of particulate organic radiocarbon in the northeast Pacific Ocean, J. Geophys. Res., 101, 2054320552, 1996.

Dunbar, R. B., Anderson, J. B., Domack, E. W.: Oceanographic influences on sedimentation along the Antarctic Continental Shelf, Antarctic Res. Ser., 45, 291-312, 1985.

Dunbar, R. B., Leventer, A. R., and Stockton, W. L.: Biogenic sedimentation in McMurdo Sound, Antarctica, Mar. Geol., 85, 155179, 1989.

Dunbar, R. B., Arrigo, K. R., Lutz, M., DiTullio, G. R., Leventer, A. R., Lizotte, M. P., Van Woert, M. P., and Robinson, D. H.: NonRedfield production and export of marine organic matter: a recurrent part of the annual cycle in the Ross Sea, in: Biogeochemistry of the Ross Sea, Antarctic Research Series Monograph, 78, edited by: DiTullo, G. R. and Dunbar, R. B., American Geophysical Union, 179-195, 2003.

Eglinton, T. I., Aliwihare, L. I, Bauer, J. E., Druffel, E. R. M., and McNichol, A. P.: Gas chromatographic isolation of individual compounds from complex matrices for radiocarbon dating, Anal. Chem., 68, 904-912, 1996.

Eglinton, T. I., Benitez-Nelson, B. C., Pearson, A., McNichol, A. P., Bauer, J. E., and Druffel, E. R. M.: Variability in radiocarbon ages of individual organic compounds from marine sediments, Science, 277, 796-799, 1997.

Eglinton, T. I., Eglinton, G., Dupont, L., Sholkovitz, E. R., Montlucon, D. and Reddy, C. M.: Composition, age, and provenance of organic matter in NW African dust over the Atlantic Ocean, Geochem. Geophys. Geosys., 3, 1-27, 2002.

Feng, X., Benitez-Nelson, B. C., Montluçon, D. B., Prahl, F. G., McNichol, A. P., Xu, L., Repeta, D. J., and Eglinton, T. I.: ${ }^{14} \mathrm{C}$ and ${ }^{13} \mathrm{C}$ characteristics of higher plant biomarkers in Washington margin surface sediments, Geochim. Cosmochim. Ac., 105, 1430, 2013.

Freeman K. H.: Isotopic biogeochemistry of marine organic carbon, in: Stable Isotope Geochemistry, Reviews in Mineralogy and Geochemistry, vol. 43, edited by: Valley, J. W. and Cole, D. R., 579-605, 2001.

Freeman K. H., Hayes J. M., Trendel J.-M., and Albrecht P.: Evidence from carbon isotope measurements for diverse origins of sedimentary hydrocarbons, Nature, 343, 254-256, 1990.

Fry, B. and Sherr, E. B.: $\delta^{13}$ C Measurements as indicators of carbon flow in marine and freshwater eosystems, Mar. Sci., 27, 13-47 1984.

Gagosian, R. B. and Peltzer, E. T.: The importance of atmospheric input of terrestrial organic material to deep sea sediments, Org. Geochem. 10, 661-669, 1986.
Gong, C. and Hollander, D. J.: Differential contribution of bacteria to sedimentary organic matter in oxic and anoxic environments, Santa Monica Basin, California, Org. Geochem., 26, 545-563, 1997.

Gibson, J. A. E., Trull, T., Nichols, P. D., Summons, R. E., and McMinn, A.: Sedimentation of C-13-rich organic matter from Antarctic sea-ice algae: A potential indicator of past sea-ice extent, Geology, 27, 331-334, 1999.

Gleitz, M., Kukert, H., Riebesell, U., and Dieckmann, G. S.: Carbon acquisition and growth of Antarctic sea ice diatoms in closed bottle incubations, Mar. Ecol. Prog. Ser., 135, 169-177, 1996.

Gordon, J. E. and Harkness, D. D.: Magnitude and geographic variation of the radiocarbon content in Antarctic marine life: implications for reservoir corrections in radiocarbon dating, Quaternary Sci. Rev., 11, 697-708, 1992.

Griffith, D. R., Martin, W. R., and Eglinton, T. I.: The radiocarbon age of organic carbon in marine surface sediments, Geochim. Cosmochim. Ac., 74, 6788-6800, 2010.

Haake, B., Rixen, T., Reemtsma, T., Ramaswamy, V., and Ittekkot, V.: Processes determining seasonal variability and interannual variability of settling particle fluxes to the deep Arabian Sea, in: Particle Flux in the Ocean, SCOPE vol. 57, edited by: Ittekkot, V., Schaefer, P., Honjo, S., and Depetris, P. J., Wiley, New York, 251-270, 1996.

Hall, B., Henderson, G., Baroni, C., and Kellogg, T.: Constant Holocene Southern Ocean ${ }^{14} \mathrm{C}$ reservoir ages and ice-shelf flow rates. Earth Planet. Sci. Lett., 296, 115-123, 2010.

Harris, P. T., O’Brien, P.E., Sedwick, P., and Truswell, E.M.: Late Quaternary history of sedimentation on the Mac. Robertson Shelf, East Antarctica: problems with ${ }^{14} \mathrm{C}$-dating of marine sediment cores, Proc. Roy. Soc. Tasmania, 130, 47-53 1996.

Hay B. J.: Particle flux in the western Black Sea in the present and over the last 5000 years: Temporal variability, sources, transport mechanisms. Ph.D. thesis, WHOI-87-44, MIT-WHOI Joint Program, 201 pp., 1987.

Hay, B. J. and Honjo, S.: Particle deposition in the present and Holocene Black Sea, Oceanogr., 2, 26-31, 1989.

Hay, B. J., Honjo, S, Kempe, S., Ittekkot, V., Degens, E. T., Konuk, T., and Izdar, E.: Interannual variability in particle flux in the southwestern Black Sea, Deep-Sea Res., 37, 911-928, 1990.

Hay, B. J., Arthur, M. A., and Dean, W.: Sediment deposition in the Late Holocene abyssal Black Sea with climatic and chronological implications, Deep-Sea Res., 38, Suppl. 2, S1211-S1235, 1991.

Hayes, J. N.: Fractionation of the isotopes of carbon and hydrogen in biosynthetic processes, in: Stable Isotope Geochemistry, Reviews in Mineralogy and Geochemistry, vol. 43, edited by: Valley, J. W. and Cole, D. R., Mineralogical society of America, Washington DC, 225-278, 2001.

Hedges J. I. and Keil R. G.: Sedimentary organic matter preservation: an assessment and speculative synthesis, Mar. Chem., 49, 81-115, 1995.

Hedges, J. I., Keil, R. G., and Benner, R.: What happens to terrestrial organic matter in the ocean?, Org. Geochem., 27, 195-212, 1997.

Hedges, J. I., Hu, F. S., Devol, A. H., Hartnett, H. E., Tsamakis, E., and Keil, R. G.: Sediment organic matter preservation; a test for selective degradation under oxic conditions, Am. J. Sci., 299, 529-555, 1999. 
Hedges, J. I., Eglinton, G., Hatcher, P. G., Kirchman, D. L., Arnosti, C., Derenne, S., Evershed, R. P., Kögel-Knabner, I., de Leeuw, J. W., Littke, R., Michaelis, W., and Rullkötter, J.: The molecularlyuncharacterized component of nonliving organic matter in natural environments, Org. Geochem., 31, 945-958, 2000.

Hedges, J. I., Baldock, J. A., Gelinas, Y., Lee, C., Peterson, M. L., and Wakeham, S. G.: Non-selective preservation of organic matter in sinking marine particles, Nature, 409, 801-804, 2001.

Honjo, S., Dymond, J., Prell, W., and Ittekkot, V.: Monsooncontrolled export fluxes to the interior of the Arabian Sea, DeepSea Res. II, 46, 1859-1902, 1999.

Hwang, J., Druffel, E., and Komada, T.: Transport of organic carbon from the California coast to the slope region: a study of $\Delta^{14} \mathrm{C}$ and $\delta^{13} \mathrm{C}$ signatures of organic compound classes, Global Biogeochem. Cy., 19, GB2018, doi:10.1029/2004GB002422, 2005.

Hwang, J., Druffel, E. R. M., and Eglinton, T. I.: Widespread influence of resuspended sediments on oceanic particulate organic carbon: Insights from radiocarbon and aluminum contents in sinking particles, Global Biogeochem. Cy., 24, GB4016, doi:10.1029/2010GB003802, 2010.

Ingalls A. E. and Pearson A.: Ten years of compound-specific radiocarbon analysis, Oceanography, 18, 18-31, 2005.

Jones, G. A. and Gagnon, A. R.: Radiocarbon chronology of Black Sea sediments, Deep-Sea Res., 41, 531-557, 1994.

Kawamura, K., Ishimura, Y., and Yamazaki, K.: Four years' observations of terrestrial lipid class compounds in marine aerosols from the western North Pacific, Global Biogeochem. Cy., 17, 1003, doi:10.1029/2001GB001810, 2003.

Key, R. M., Kozyr, A., Sabine, C. L., Lee, K., Wanninkhof, R., Bullister, J. L., Feely, R. A., Millero, F. J., Mordy, C., and Peng, T.-H.: A global ocean carbon climatology: Results from Global Data Analysis Project (GLODAP), Global Biogeochem. Cy., 18, GB4031, doi:10.1029/2004GB002247, 2004.

Komada, T., Druffel, E., and Hwang, J.: Sedimentary rocks as sources of ancient organic carbon to the ocean: an investigation through $\Delta^{14} \mathrm{C}$ and $\delta^{13} \mathrm{C}$ signatures of compound classes, Global Biogeochem. Cy., 19, GB2017, doi:10.1029/2004GB002347, 2005.

Kusch, S., Rethemeyer, J., Schefuß, E., and Mollenhauer, G.: Controls on the age of vascular plant biomarkers in Black Sea sediments, Geochim. Cosmochim. Ac., 74, 7031-7047, 2010.

Lee, C., Murray, D. W., Barber, R. T., Buesseler, K. O., Dymond, J., Hedges, J. I., Honjo, S., Manganini, S. J., Marra, J., Moser, C., Peterson, M. L., Prell, W. L., and Wakeham, S. G.: Particulate organic carbon fluxes: compilation of results from the 1995 US JGOFS Arabian Sea Process Study, Deep-Sea Res. II, 45, 2489 2501, 1998.

Lee, C., Wakeham, S. G., and Arnosti, C.: Particulate organic matter in the sea: the composition conundrum, Ambio, 33, 565-575, 2004

Levin, I. and Kromer, B.; Twenty years of atmospheric ${ }^{14} \mathrm{CO}_{2}$ observations at Schauinsland, Radiocarbon, 39, 205-218, 1997.

Licht, K. J., Jennings, A. E., Andrews, J. T., and Williams, K. M.: Chronology of late Wisconsin ice retreat from the western Ross Sea, Antarctica, Geol., 24, 223-226, 1996.

McNichol, A. P. and Aluwihare, L. I.: The power of radiocarbon in biogeochemical studies of the marine carbon cycle: Insights from studies of dissolved and particulate organic carbon (DOC and POC), Chem. Rev. 107, 443-466, 2007.
McNichol A. P., Osborne E. A., Gagnon A. R., Fry B., and Jones G. A.: TIC, TOC, DIC, DOC, PIC, POC - unique aspects in the preparation of oceanographic samples for ${ }^{14} \mathrm{C}$-AMS, Nucl. Instr. Meth. Phys. Res., 92, 162-165, 1994.

Mollenhauer, G. and Eglinton, T. I.: Diagenetic and sedimentological controls on the composition of organic matter preserved in California Borderland Basin sediments, Limnol. Oceanogr., 52, 558-576, 2007.

Mollenhauer, G., Eglinton, T. I., Ohkouchi, N., Schneider, R. R., Müller, P. J., Grootes, P. M., and Rullkötter, J.: Asynchronous alkenone and foraminifera records from the Benguela Upwelling System, Geochim. Cosmochim. Ac., 67, 2157-2171, 2003.

Ohkouchi, N. and Eglinton, T. I.: Compound-specific radiocarbon dating of Ross Sea sediments: A prospect for constructing chronologies in high-latitude oceanic sediments, Quart. Geochronol., 3, 235-243, 2008.

Ohkouchi, N., Eglinton, T. I., Keigwin, L. D., and Hayes, J. M.: Spatial and temporal offsets between proxy records in a sediment drift, Science, 298, 1224-1227, 2002.

Ohkouchi, N., Eglinton, T. I., and Hayes, J. M.: Radiocarbon dating of individual fatty acids as a tool for refining Antarctic Margin sediment chronologies, Radiocarbon, 45, 17-24, 2003.

Ohkouchi, N., Xu, L., Reddy, C. M., Montluçon, D., and Eglinton, T. I.: Radiocarbon dating of alkenones from marine sediments, I. Isolation protocol, Radiocarbon, 47, 401-412, 2005.

Passier, H. F., Luther, G.W, III., and de Lange, G. J.: Early diagenesis and sulfur speciation in sediments of the Oman Margin, northwestern Arabian Sea, Deep-Sea Res., 44, 1361-1380, 1997.

Pearson, A.: Biogeochemical applications of compound-specific radiocarbon analysis, Ph.D. Thesis, Woods Hole Oceanographic Institution/Massachusetts Institute of Technology, Woods Hole, MA, 248 pp., 2000.

Pearson, A.: Pathways of carbon assimilation and their impact on organic matter values of $\delta^{13} \mathrm{C}$, in: Handbook of Hydrocarbon and Lipid Microbiology: Microbial interactions with hydrocarbons, oils, fats, and related hydrophobic substrates and products, edited by: Timmis, K., Springer-Verlag Berlin, 143-156, 2010.

Pearson, A. and Eglinton, T. I.: The origin of $n$-alkanes in Santa Monica Basin surface sediment: a model based on compoundspecific $\Delta^{14} \mathrm{C}$ and $\delta^{13} \mathrm{C}$ data, Org. Geochem. 31, 1103-1116, 2000.

Pearson, A., McNichol, A. P., Schneider, R. J., and von Reden, K. F.: Microscale AMS ${ }^{14} \mathrm{C}$ measurement at NOSAMS, Radiocarbon, 40, 61-76, 1998.

Pearson, A., McNichol, A. P., Benetiz-Nelson, B. C., Hayes, J. M., and Eglinton, T. I.: Origins of lipid biomarkers in Santa Monica Basin surface sediment: A case study using compoundspecific $\Delta^{14} \mathrm{C}$ analysis, Geochim. Cosmochim. Ac., 65, 31233137, 2001.

Pearson A., Seewald J. S., and Eglinton T. I.: Bacterial incorporation of relict carbon in the hydrothermal environment of Guaymas Basin, Geochim. Cosmochim. Ac., 69, 5477-5486, 2005.

Petsch, S. T., Eglinton, T. I., and Edwards, K. J.: ${ }^{14} \mathrm{C}$-dead living biomass: Evidence for microbial assimilation of ancient organic carbon during shale weathering, Science, 292, 1127-1131, 2001.

Petsch, S. T., Edwards, K. J., and Eglinton, T. I.: Abundance, distribution, and $\delta^{13} \mathrm{C}$ analysis of microbial phospholipid-derived fatty acids in a black shale weathering profile, Org. Geochem., 34, 731-743, 2003. 
Prahl, F. G., Muehlhausen, L. A., and Lyle, M.: An organic geochemical assessment of oceanographic conditions at MANOP Site C over the past 26000 years, Paleoceanogr, 4, 495-510, 1989.

Premuzic E. T., Benkovitz C. M., Gaffney J. S., and Walsh J. J.: The nature and distribution of organic matter in the surface sediments of world oceans and seas, Org. Geochem., 4, 63-77, 1982.

Ramage, C. S., Miller, F. R., and Jeffries, C.: Meteorological Atlas of the International Indian Ocean Expedition: The Surface Climate of 1963, 1964, US National Science Foundation and India Meteorological Department, 1972.

Rau, G. H., Takahashi, T., Des Marias, D. J., and Sullivan, C. W.: Particulate organic matter ${ }^{\delta} \mathrm{C}$ variations across the Drake Passage, J. Geophys. Res., 96, 15131-15135, 1991a.

Rau, G. H., Sullivan, C. W., and Gordon, L. I.: $\delta^{13} \mathrm{C}$ and $\delta^{15} \mathrm{~N}$ variations in Weddell Sea particulate organic matter, Mar. Chem., 35, 355-369, 1991b.

Ross D. A. and Degens, E. T.: Recent sediments of the Black Sea, in: The Black Sea - Geology, chemistry, and biology, Memoirs of the American Association of Petroleum Geologists, 20, edited by: Degens, E. T. and Ross, D. A., 183-199, 1974.

Sackett, W. M., Poag, C. W., and Eadie, B. J.: Kerogen recycling in the Ross Sea, Antarctica, Science, 185, 1045-1047, 1974.

Siani, G., Paterne, M., Arnold, M., Bard, E., Métivie, B., Tisnerat, N., and Bassinot, F.: Radiocarbon reservoir ages in the Mediterranean Sea and Black Sea, Radiocarbon, 2, 271-280, 2000.

Sirocko F. and Sarnthein M.: Wind-borne deposits in the Northwestern Indian Ocean: Record of Holocene sediments versus satellite data, in: Paleoclimatology and Paleometeorology: Modern and Past Patterns of Global Atmospheric Transport, Vol. 282 in NATO ASI Series, Series C, edited by: Leinin, M. and Sarnthein, M., Kluwer, 401-433, 1989.

Smith, S. L., Codispoti, L. A., Morrison, J. M., and Barber, R. T.: The 1994-1996 Arabian Sea Expedition: an integrated, interdisciplinary investigation of the response of the northwestern Indian Ocean to monsoonal forcing, Deep-Sea Res. II, 45, 1905-1915, 1998.

Southon, J., Kashgarian, M., Fontugne, M., Metivier, B., and Yim, W.-S.: Marine reservoir corrections for the Indian Ocean and Southeast Asia, Radiocarbon, 44, 167-180, 2002.

Stuiver, M. and Braziunas, T. F.: Modelling atmospheric ${ }^{14} \mathrm{C}$ influences and ${ }^{14} \mathrm{C}$ ages of marine samples to $10000 \mathrm{BP}$, Radiocarbon, 35, 137-189, 1993.

Stuiver, M. and Ostlund, H. G.: GEOSECS Indian Ocean and Mediterranean radiocarbon, Radiocarbon, 25, 1-29, 1983.

Stuiver, M. and Polach, H. A.: Discussion: Reporting of ${ }^{14} \mathrm{C}$ data, Radiocarbon, 19, 355-363, 1977.

Villinski, J. C., Dunbar, R. B., and Mucciarone, D. A.: Carbon 13/Carbon 12 ratios of sedimentary organic matter from the Ross Sea, Antarctica: A record of phytoplankton bloom dynamics, J. Geophys. Res., 105, 14163-14172, 2000.

Volkman, J. K.: Lipid markers for marine organic matter, in: The Handbook of Environmental Chemistry, edited by: Hutzinger, O.; Vol 2: Reactions and processes, Part N, Marine organic matter: Biomarkers, isotopes and DNA, edited by: Volkman, J. K. Springer, Berlin, 27-70, 2006.

Volkman, J. R, Eglinton, G., Corner, E. D. S., and Forsberg, T. E. V.: Long-chain alkenes and alkenones in the marine coccolithophorid Emiliania huxleyi, Phytochem., 19, 2619-2622, 1980. von Reden, K. F., Schneider, R. F., McNichol, A. P., and Pearson, A.: ${ }^{14} \mathrm{C}$-AMS measurements of $<100 \mu \mathrm{g}$ samples with a highcurrent system, Radiocarbon 40, 247-253, 1998.

Wakeham, S. G.: Organic matter from a sediment trap experiment in the equatorial Atlantic: wax esters, steryl esters, triacylglycerols, and alkyldiacylglycerols, Geochim. Cosmochim. Ac., 46, 22392257, 1982.

Wakeham, S. G.: Aliphatic and polycyclic aromatic hydrocarbons in Black Sea sediments, Mar. Chem., 53, 187-205, 1996.

Wakeham, S. G. and Canuel, E. A.: Degradation and preservation of organic matter in marine sediments, in: The Handbook of Environmental Chemistry, Vol. 2, Reactions and Processes, edited by: Hutzinger, O.; Vol. 2. Marine Organic Matter: Biomarkers, Isotopes and DNA, edited by: Volkman, J. K., Springer-Verlag, Berlin, 295-321, 2006.

Wakeham, S. G., Beier, J. A., and Clifford, C. H.: Organic matter sources in the Black Sea as inferred from hydrocarbon distributions, in: Black Sea Oceanography, edited by: Izdar, E. and Murray, J. W., Kluwer, 319-341, 1991.

Wakeham, S. G., Lee, C., Hedges, J. I., Hernes, P. J., and Peterson, M. L.: Molecular indicators of diagenetic status in marine organic matter, Geochim. Cosmochim. Ac., 61, 5363-5369, 1997.

Wakeham, S. G., Peterson, M. L., Hedges J. I., and Lee, C.: Lipid biomarker fluxes in the Arabian Sea: with a comparison to the Equatorial Pacific Ocean, Deep-Sea Res. II., 49, 2265-2301, 2002.

Wakeham, S. G., McNichol, A. P., Kostka, J., and Pease, T. K.: Natural abundance radiocarbon as a tracer of assimilation of petroleum carbon by bacteria in salt marsh sediments, Geochim. Cosmochim. Ac., 70, 1761-1771, 2006.

Wang, X.-C., Druffel, E. R. M., Griffin, S., Lee, C., and Kashgarian, M.: Radiocarbon studies of organic compound classes in plankton and sediment of the northeastern Pacific Ocean, Geochim. Cosmochim. Ac., 62, 1365-1378, 1998.

Wang, X.-C. and Druffel, E. R. M.: Radiocarbon and stable carbon isotope compositions of organic compound classes in sediments from the NE Pacific and Southern Oceans, Mar. Chem., 73, 6581,2001 .

Yunker, M. B., Macdonald, R. W., Cretney, W. J., Fowler, B. R., and McLaughlin, F. A.: Alkane, terpene and polycyclic aromatic hydrocarbon geochemistry of the Mackenzie River and Mackenzie shelf: Riverine contributions to Beaufort Sea coastal sediment, Geochim. Cosmochim. Ac., 57, 3041-3061, 1993.

Yunker, M. B., Backus, S. M., Pannatier, E. G., Jeffries, D. S., and Macdonald, R. W.: Sources and significance of alkane and PAH hydrocarbons in Canadian arctic rivers, Estuar. Coast. Shelf S., 55, 1-31, 2002.

Zafiriou, O. C., Gagosian, R. B., Peltzer, E. T., and Alford, J. B.: Air-to-sea fluxes of lipids at Enewetak Atoll, J. Geophys. Res., 90, 2409-2423, 1985.

Zonneveld, K. A. F., Versteegh, G. J. M., Kasten, S., Eglinton, T., Emeis, K.-C., Huguet, C., Koch, B., de Lange, G. J., de Leeuw, J. W., Middelburg, J. J., Mollenhauer, G., Prahl, F., Rethemeyer, J., and Wakeham, S.: Selective preservation of organic matter in marine environments; processes and impact on the fossil record, Biogeosci., 7, 483-511, 2010. 